\title{
Soil temperature response to 21st century global warming: the role of and some implications for peat carbon in thawing permafrost soils in North America
}

\author{
D. Wisser ${ }^{1}$, S. Marchenko ${ }^{2}$, J. Talbot ${ }^{1}$, C. Treat $^{1}$, and S. Frolking ${ }^{1}$ \\ ${ }^{1}$ Complex Systems Research Center, Institute for the Study of Earth, Oceans, and Space, University of New Hampshire, \\ Durham, NH 03824, USA \\ ${ }^{2}$ Geophysical Institute, Permafrost Lab, University of Alaska Fairbanks, Fairbanks, AK 99775, USA
}

Received: 10 February 2011 - Published in Earth Syst. Dynam. Discuss.: 17 February 2011

Revised: 18 May 2011 - Accepted: 15 June 2011 - Published: 24 June 2011

\begin{abstract}
Northern peatlands contain a large terrestrial carbon pool that plays an important role in the Earth's carbon cycle. A considerable fraction of this carbon pool is currently in permafrost and is biogeochemically relatively inert; this will change with increasing soil temperatures as a result of climate warming in the 21 st century. We use a geospatially explicit representation of peat areas and peat depth from a recently-compiled database and a geothermal model to estimate northern North America soil temperature responses to predicted changes in air temperature. We find that, despite a widespread decline in the areas classified as permafrost, soil temperatures in peatlands respond more slowly to increases in air temperature owing to the insulating properties of peat. We estimate that an additional $670 \mathrm{~km}^{3}$ of peat soils in North America, containing $\sim 33 \mathrm{PgC}$, could be seasonally thawed by the end of the century, representing $\sim 20 \%$ of the total peat volume in Alaska and Canada. Warming conditions result in a lengthening of the soil thaw period by $\sim 40$ days, averaged over the model domain. These changes have potentially important implications for the carbon balance of peat soils.
\end{abstract}

\section{Introduction}

Northern peatlands cover $\sim 10 \%$ of the land north of $45^{\circ} \mathrm{N}$ and contain $\sim 500 \mathrm{Pg}$ carbon (C), almost entirely as peat (Yu et al., 2010). This relatively large carbon pool within

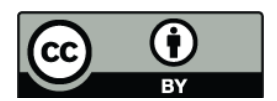

Correspondence to: D. Wisser (dominik.wisser@unh.edu@) one to a few meters of the land surface confers the important role of peatlands in the earth's carbon fluxes (Gorham, 1991). Changing environmental conditions could potentially impact the exchanges of carbon dioxide $\left(\mathrm{CO}_{2}\right.$, Limpens et al., 2008), methane $\left(\mathrm{CH}_{4}\right.$, Christensen et al., 2004), dissolved organic carbon (DOC, Frey and Smith, 2005) and nitrous oxide $\left(\mathrm{N}_{2} \mathrm{O}\right.$, Elberling et al., 2010) between peatlands and the atmosphere through a number of direct and indirect effects, and thereby change the role of peatlands in the global climate system. In particular, climate warming can directly affect $\mathrm{C}$ fluxes from peatlands. Ecosystem respiration has been found to increase in response to a $1{ }^{\circ} \mathrm{C}$ soil warming in a subarctic bog (Dorrepaal et al., 2009) and to vary depending on seasonal temperature patterns (Lund et al., 2010). Methane emissions are also strongly dependent on soil temperature (Treat et al., 2007; Kettridge and Baird, 2008).

An estimated one third of Northern peatlands is currently located in permafrost regions (Tarnocai, 2006; Smith et al., 2007). Permafrost is usually defined as ground material that remains at or below $0^{\circ} \mathrm{C}$ for a period of at least two years, for natural climatic reasons (van Everdingen, 1998) and represents an important control on the peat atmosphere and peat hydrosphere interactions. Biogeochemical processes in peatlands with permafrost are strongly influenced by the maximum depth of the $0^{\circ} \mathrm{C}$ isotherm (the active layer thickness, ALT) that separates frozen (and relatively inert) peat from seasonally-thawed (and biologically active) peat. A deepening of the active layer in recent decades, a general degradation of permafrost (Romanovsky and Osterkamp, 1997; Oberman and Mazhitova, 2001; Camill, 2005; Åkerman and Johansson, 2008; Anisimov and Reneva, 2009; Simon and Serge, 2009) and the projected increases in the active layer

Published by Copernicus Publications on behalf of the European Geosciences Union. 
in the next decades (Stendel and Christensen, 2002; Arctic Climate Impact Assessment (ACIA), 2004; Romanovsky et al., 2007; Marchenko et al., 2008) have raised questions on the potential release of carbon from peatlands as a result of global warming (Christensen et al., 2004; Turetsky et al., 2007). Anisimov (2007) predicted an overall increase in the seasonal thaw depth of $30 \%$ by 2080 , which resulted in a 20-30\% increase in $\mathrm{CH}_{4}$ emissions from Russian peatland regions.

Soil temperatures are not only influenced by air temperatures but also by the presence or absence of an insulating layer of snow on the surface (Sturm et al., 1997). The response of soil temperatures to changes in air temperature strongly depends on the temporal distribution, depth, and density of the snowpack during the winter (Lawrence and Slater, 2010). The snowpack generally insulates the soil from the cold air and changes in the snowpack can therefore lead to more soil cooling (if the snowpack decreases) or warmer winter soil temperatures and permafrost degradation with a deeper snowpack (Christensen et al., 2004; Payette et al., 2004; Stieglitz et al., 2003).

Finally, it is the thermal and hydraulic properties of the peat itself that lead to different responses to air temperature in peat soil when compared to mineral soils that have prompted their explicit parameterization in land surface models (e.g. Beringer et al., 2001). Thermal properties of peat soil are strongly related to the peat soil moisture (Farouki, 1981; O'Donnell et al., 2009), which depends on the position of the water table, both of which are likely to change under future climate conditions. The insulating properties of peat are expected to preserve permafrost in peatland areas from severe degradation (Shur and Jorgenson, 2007; Yi et al., 2007). Currently, relict permafrost formed during the Little Ice Age is found in isolated patches within Canadian bogs despite warmer air temperatures (Halsey et al., 1995; Vitt et al., 1994). Additionally, peat depth is an important control on the active layer depth (Fukui et al., 2008; Yi et al., 2006). It is therefore imperative to consider the spatial distribution of those properties in attempts to model the future distribution of permafrost areas and the role of peatlands in the global climate system. A layer of organic material $(<0.3 \mathrm{~m})$ on top of mineral soil is a dominant feature of northern forest and tundra soils that are not classified as peatlands (Rinke et al., 2008). This layer plays an important role in exchanges of water, energy and carbon and the representation of this thin organic layer in ecosystem models is therefore also important (Yi et al., 2009).

A number of attempts have been made to incorporate peatlands and organic soil layers in Earth system models (e.g. Rawlins et al., 2003; Lawrence and Slater, 2008; Wania et al., 2009) and these approaches have assumed a spatially uniform depth of the organic layer. Here, we present the first attempt to estimate soil temperatures in peatlands using a grid cell based framework with partitioning of the grid cell into a peat and non-peat fraction and explicitly taking into account the spatially varying depth of peat over a large spatial domain. This allows for an assessment of the impact of peat depth on soil temperatures and the relative differences in soil temperatures for peat soils and mineral soils and an assessment of the frozen and unfrozen peat volumes under changing climate. We use a thermodynamic model and soil moisture from a hydrological model to predict soil temperature in peat and mineral soil and estimate areas and thawed volumes of these soil fractions under future climate conditions. Assuming a carbon concentration and carbon content for peat and mineral soils, the total soil carbon in Northern North America that will change from being permanently frozen to seasonally thawed can be assessed.

We will first present an overview of the model and the data sets and then discuss the importance of peat depth for the prediction of peat soil temperatures by analyzing results from transient simulations of soil temperatures in peatlands in North America under predicted climate conditions for the period 2001-2100.

\section{Data and methods}

\subsection{The GIPL 2.0 model}

We used the modified Geophysical Institute Permafrost Lab model (GIPL 2.0; Marchenko et al., 2008) to simulate soil temperatures and freezing and thawing depths in peatland and non-peatland soils. Details of the numerical algorithm are provided elsewhere (Marchenko, 2001; Marchenko et al., 2008 ) and only a short overview is given here. GIPL calculates soil temperatures at different depths by applying a finite difference scheme to solve the 1-D heat transfer equation with phase change numerically and is therefore applicable to transient simulations. The version applied here computes soil temperatures at a $30 \mathrm{~min} \times 30 \mathrm{~min}$ spatial resolution. GIPL takes into account spatially varying thermal properties of the soil layers and estimates the amount of unfrozen water based on those properties.

The depth of the soil column and its importance for longer timescale models of soil temperature has been recognized (e.g. Alexeev et al., 2007; Lawrence et al., 2008). The computational domain is therefore extended to a depth of $100 \mathrm{~m}$ at which a spatially uniform geothermal heat flux is set as a boundary condition. The upper boundary condition at the soil or peat surface is determined by the air temperature, or, if a snowpack is present, by a heat flux through the snowpack that is calculated taking into account the depth and density of the snow (Fig. 1).

We applied the model with a time step of $24 \mathrm{~h}$ and computed soil temperatures at 114 computation nodes in the soil column, with space between nodes increasing with depth. The entire model domain (Fig. 2) covered a total area of 11.59 million $\mathrm{km}^{2}$ in 8078 grid cells. In areas with peatlands, soil temperatures are calculated for peatlands and mineral 
soils separately. There was no lateral transport of heat between the peat and the non-peat fraction of a grid cell and no lateral transport of heat between neighboring grid cells. For both peat and non-peat calculations, we set the initial soil temperature, $T_{\text {ini }}\left[{ }^{\circ} \mathrm{C}\right]$, at depth $z[\mathrm{~m}]$ as $T_{\text {ini }}(z)=T_{\mathrm{m}} G_{0} z$ where $T_{\mathrm{m}}$ is the mean annual air temperature $\left[{ }^{\circ} \mathrm{C}\right]$ and $G_{0}$ $\left[{ }^{\circ} \mathrm{C} \mathrm{m}^{-1}\right]$ is the geothermal gradient (set to 0.015 ). We computed time series of soil temperature for the period 20012100 after a 100-year spin-up period using contemporary (2001-2010) climatologies of temperature and precipitation.

The latent heat of the freeze-thaw phase change is implemented through the apparent volumetric heat capacity over a small temperature range near the freezing temperature of water $\left(T_{\mathrm{f}}=0^{\circ} \mathrm{C}\right), C(z, T)+\delta(T) Q(z)$ at the freezing front $T(z, \tau)=T_{\mathrm{f}}$, where $Q(z)$ is the latent heat of ice fusion or specific enthalpy of fusion $\left(Q_{\mathrm{f}}=334\left[\mathrm{M} \mathrm{J} \mathrm{m}^{-3}\right]\right)$ and $\delta(T)$ is the Dirac delta function having the following properties:

$\delta_{\Delta}\left(T-T_{\mathrm{f}}\right)=\left\{\begin{array}{l}\frac{1}{2 \Delta} \text { if }\left|T-T_{\mathrm{f}}\right| \leq \Delta \\ \delta \rightarrow 0, \text { if }\left|T-T_{\mathrm{f}}\right|>\Delta\end{array}\right.$

where $\Delta$ is the width of a half-interval of $\tilde{C}$ (volumetric heat capacity) and $\tilde{\lambda}$ (thermal conductivity) smoothing range, set to $0.08^{\circ} \mathrm{C}$. The latent heat of ice formation-fusion is therefore represented through apparent volumetric heat capacity $[\delta(T) Q(z)]$ at the phase freezing front so that the heat transfer problem can be solved without explicit representation of freezing front coordinates. The smoothed volumetric heat capacity $\tilde{C}\left[\mathrm{M} \mathrm{J} \mathrm{m}^{-3} \mathrm{~K}^{-1}\right]$ at temperature $T\left[{ }^{\circ} \mathrm{C}\right]$ is approximated taking into account the volumetric heat capacity $C_{\mathrm{vol}}$ of the solid materials (peat or mineral soil; see below), the soil water/ice content $\theta$, the unfrozen water content $\theta_{\mathrm{u}}$, and the latent heat of ice fusion $Q(z)$ :

$\tilde{C}(T)=\left\{\begin{array}{lc}C_{\text {vol }}+C_{\text {ice }}\left(\theta-\theta_{\mathrm{u}}\right)+C_{\mathrm{w}} \theta_{\mathrm{u}} & T<T_{\mathrm{f}}-\Delta \\ C_{\text {vol }}+0.5 C_{\text {ice }}\left(\theta-\theta_{\mathrm{u}}\right)+0.5 C_{\mathrm{w}}\left(\theta-\theta_{\mathrm{u}}\right)+Q \theta / 2 \Delta & T_{\mathrm{f}}-\Delta \leq T \leq T_{\mathrm{f}}+\Delta \\ C_{\text {vol }}+C_{\mathrm{w}} \theta & T>T_{\mathrm{f}}+\Delta\end{array}\right.$

where $C_{\mathrm{w}}$ and $C_{\text {ice }}$ are the heat capacity values for water and ice respectively $\left(4.18\right.$ and $\left.1.9 \mathrm{M} \mathrm{J} \mathrm{m}^{-3} \mathrm{~K}^{-1}\right)$.

Unfrozen water $\theta_{\mathbf{u}}$ is the amount of water in the soil $(\theta)$ that remains unfrozen in the form of a thin layer around the soil particles. It can improve the transfer of heat in frozen soils (Farauki, 1981) and can retard the thermal response of the soil to air temperature changes (Romanovsky and Osterkamp, 2000). Taking into account frozen water in soil temperature models can therefore significantly improve the simulations. The amount of unfrozen water depends on the soil type and shows significant variations in space. We calculated unfrozen water for temperatures below a predefined threshold $c$ (set to $-0.01^{\circ} \mathrm{C}$ ), depending on the soil type as (Tice et al., 1976):

$\theta_{\mathrm{u}}=a|c-T|^{b}$

where $a$ and $b$ are soil type specific shape parameters that were set to 0.1 and -0.7 for sand and to 0.5 and -0.7 for silt and clay soils. Unfrozen water for the mineral soil in a

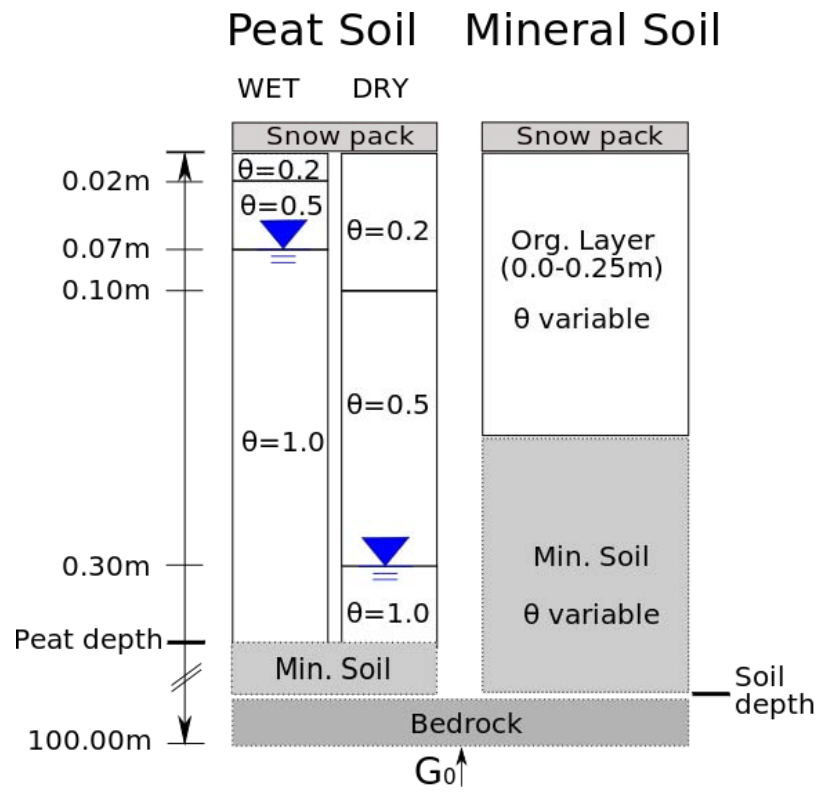

Fig. 1. Conceptual overview of the water level and water content $(\theta)$ in peatland for the wet (water table at $0.07 \mathrm{~m}$ ) and dry scenario (water table at $0.30 \mathrm{~m}$ ) and the organic layer in mineral soils. $G_{0}$ is the geothermal heat flux. Mineral soil layer depth, snowpack depth, and bedrock depth are not drawn to scale.

grid cell was computed as the weighted average of the unfrozen water for sand, silt, and clay. Unfrozen water content is typically very small in peatland soils (Romanovsky and Osterkamp, 2000; Kujala et al., 2008) and was neglected in our model.

\subsubsection{Snow dynamics}

Heat transport in snow is largely dependent on the microstructure of the snow (pore and grain distribution and size) which is difficult to quantify (Sturm et al., 1997), particularly for continental-scale simulations. The thermal conductivity of snow is therefore often calculated using empirical functions that are based on measurable properties of snow.

We used the empirical equation of Proskuryakov (1999) (e.g. Ershov, 2004), which calculates the heat flux through the snow pack into the soil as a function of snow depth $D_{\mathrm{s}}$ $[\mathrm{m}]$ and snow density $\rho_{\mathrm{s}}\left[\mathrm{kg} \mathrm{m}^{-3}\right]$ :

$\alpha=\frac{1}{\alpha_{0}}+\frac{D_{\mathrm{s}}}{0.018+0.00087 \rho_{\mathrm{s}}}$

where $\alpha_{0}$ [set to $20.14 \mathrm{~W} \mathrm{~m}^{-2} \mathrm{~K}^{-1}$ ] is the averaged factor of convection heat exchange at the surface of snow and $\alpha$ is the snow thermal resistivity. The thermal conductivity increases with increasing snow density and is therefore higher later in the snow season.

To simulate spatially varying fields of snow density and snow depth, we implemented a simple snow accumulation/ snow melt module of the $\mathrm{WBM}_{\text {plus }}$ hydrological model 


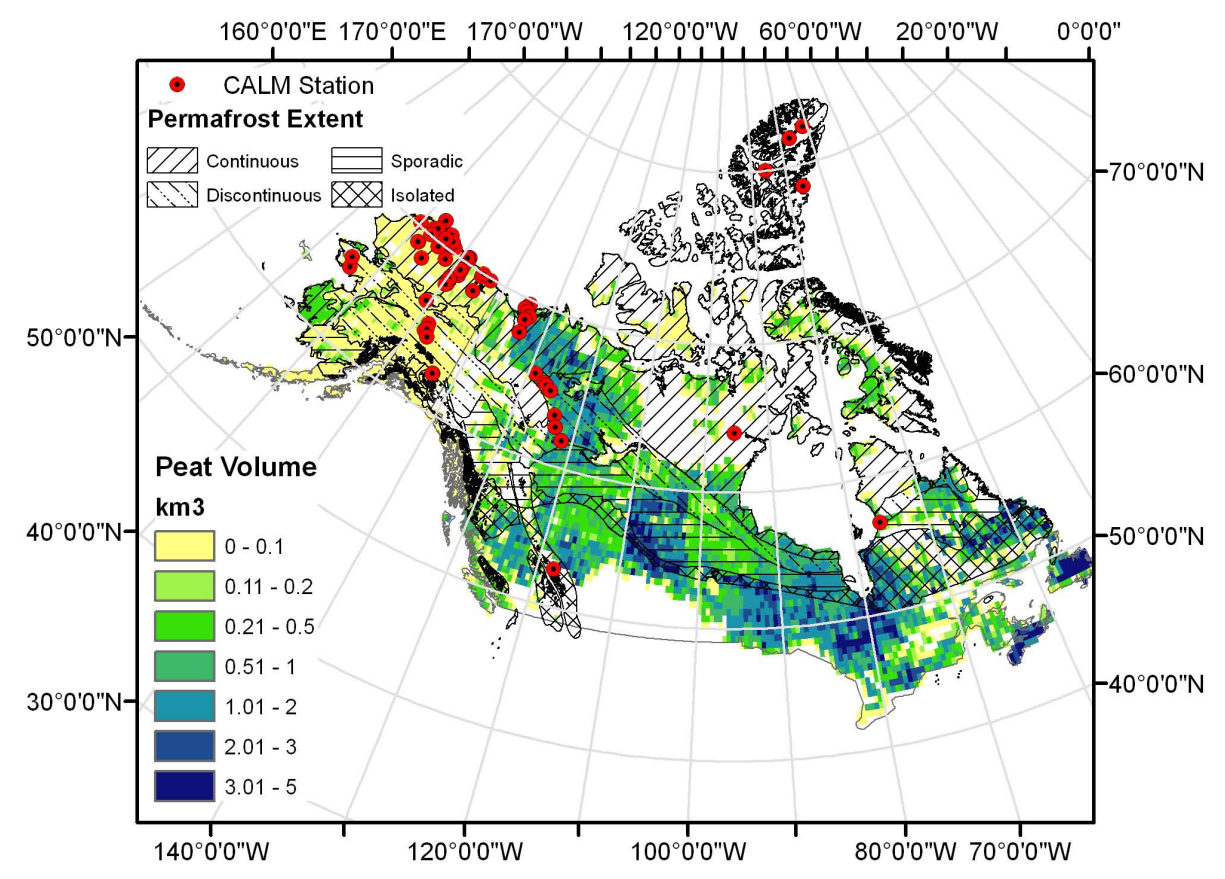

Fig. 2. Estimated peat volume (from the NSCD database) in each 30min grid cell, distribution of permafrost under contemporary conditions, and location of the CALM sites in the model domain. Permafrost classification is from Brown et al. (2001). Southern boundary defined by Tarnocai et al. (2009) soils database.

(Wisser et al., 2010). In this model, it is assumed that precipitation falls as snow if the daily air temperature is below a temperature threshold $\left[-1^{\circ} \mathrm{C}\right]$ and accumulates a snow pack [mm snow water equivalent, SWE].

Melting from the snow pack occurs when daily air temperature is above $1{ }^{\circ} \mathrm{C}$ as a function of daily air temperature and rainfall (Willmott et al., 1985):

$M_{\mathrm{s}}=2.63+2.55 T_{\mathrm{m}}+0.0912 T_{\mathrm{m}} P$

where $M_{\mathrm{s}}[\mathrm{mm}]$ is the snowmelt, $T_{\mathrm{m}}\left[{ }^{\circ} \mathrm{C}\right]$ is the mean daily air temperature, and $P[\mathrm{~mm}]$ is the daily precipitation.

The density of snow can change by an order of magnitude from wild, fresh snow to compacted, settled snow later in the season as a result of metamorphism. To calculate the snow depth during the entire snow season for each grid cell we assumed an initial snow density $\rho_{\mathrm{s}}\left[\mathrm{kg} \mathrm{m}^{-3}\right]$ of 150 at the onset of the winter (defined as the middle of the first month where the mean air temperature is below $-1{ }^{\circ} \mathrm{C}$ ) and a linear increase in snow density of $3 \mathrm{~kg} \mathrm{~m}^{-3}$ day $^{-1}$ throughout the winter based on regional estimates of snow depth by Gray and Prowse (1993) so the depth of snow for each time step can be calculated as $D_{\mathrm{s}}=\mathrm{SWE} / \rho_{\mathrm{s}}$.

\subsection{Soil thermal properties}

Soil apparent volumetric heat capacity $C_{\mathrm{vol}}\left[\mathrm{J} \mathrm{m}^{-3} \mathrm{~K}^{-1}\right]$ and soil thermal conductivity $\lambda\left[\mathrm{W} \mathrm{m}^{-1} \mathrm{~K}^{-1}\right]$ ) are calculated as the volume weighted average values for the fractions of solid material (peat or mineral soil), and water. The depth of the organic layer on top of mineral soil depends on soil type, vegetation, and land cover. We used the $0.5^{\circ}$ version of the MODIS land cover map (Friedl et al., 2002) to assign organic layer depths to land cover classes (Table 1). The thermal properties of the organic layer were assumed to be the same as the peat thermal properties. The total volume of this non-peat organic layer overlaying mineral soils in the model domain is $1173 \mathrm{~km}^{3}$, and its depth ranges from 0 to 0.25 and is $0.12 \mathrm{~m}$ on average.

\subsubsection{Thermal properties of mineral soils}

Heat capacity c for dry mineral soils was calculated using an empirical relationship between bulk density and heat capacity as (Global Soil Data Task Group, 2002):

$C_{\mathrm{vol}}=\left(0.07+0.748 \rho_{\min }\right)\left[\mathrm{M} \mathrm{J} \mathrm{m}^{-3} \mathrm{~K}^{-1}\right]$

where $\rho_{\min }\left[\mathrm{g} \mathrm{cm}^{-3}\right]$ is the bulk density of the dry mineral soil. The total heat capacity of the wet soil was computed as a function of temperature and $C_{\mathrm{vol}}$ (Eq. 2). Heat capacity for dry soils varied between 0.2 and $1.35 \mathrm{M} \mathrm{J} \mathrm{m}^{-3} \mathrm{~K}^{-1}$ and averaged $0.89 \mathrm{M} \mathrm{J} \mathrm{m}^{-3} \mathrm{~K}^{-1}$.

The relationship between soil properties, soil water content, and the thermal conductivity $\lambda$ is highly complex (Yang and Koike, 2005) and a number of empirical relationships have been developed to parameterize the thermal conductivity of different soils. A widely used relationship for the 
Table 1. Depth of organic layer in the mineral soil partition in each grid cell for different MODIS land cover classes. Based on Bockheim et al. (1997). The permanent wetlands class does not include peatlands.

\begin{tabular}{ll}
\hline Modis Land cover class & Org. Layer, m \\
\hline Water bodies & 0 \\
Evergreen needleleaf forests & 0.20 \\
Deciduous broadleaf forests & 0.05 \\
Mixed forests & 0.15 \\
Closed shrubland & 0.15 \\
Open shrubland & 0.10 \\
Woody savannas & 0.15 \\
Savannas & 0.05 \\
Grassland & 0.10 \\
Permanent wetlands* & 0.25 \\
Croplands & 0.10 \\
Cropland/natural veg mosaic & 0.10 \\
Permanent snow/ice & 0 \\
Barren/sparsely vegetated & 0.02 \\
\hline
\end{tabular}

thermal conductivity of the soil as a function of soil moisture is from Hendrickx et al. (2008):

$\lambda(\theta)=A+B \theta-(A-D) e^{-(C \theta)^{4}}$

where $A, B, C, D$ are empirical coefficients that are determined based on the composition of the soil (the volume fractions of quartz, other minerals, total solids, and clay, that are, in turn, estimated from the soil fractions of sand, silt, and clay). The volume and weight fractions of sand, silt, and clay in each grid cell, are available from the standardized data set of soil horizon depth and textures for up to 15 soil horizons compiled by Webb et al. (2000). The soil depth (computed as the sum of all soil layer depths in each grid cell) in the study region generally varies between 0.0 and $9.7 \mathrm{~m}$ and is $4.25 \mathrm{~m}$ on average.

Temporally and spatially varying fields of soil moisture in mineral soils were calculated using the $\mathrm{WBM}_{\text {plus }}$ hydrological model (Wisser et al., 2010) that computes components of the hydrological cycle based on soil hydraulic properties and fields of climate data.

Potential evapotranspiration in $\mathrm{WBM}_{\text {plus }}$ was calculated as a function of air temperature and day length using the Hamon relationship (Hamon, 1963).

We assumed that the soil is underlain by bedrock up to the lower boundary of our model $(100 \mathrm{~m})$, assumed the same water content as in the upper layers, and computed thermal properties like the lowest layer of the soil layers. This is similar to the approach used by Lawrence et al. (2008) but different from the assumption of Zhang et al. (2008b) of no water in bedrock.

\subsubsection{Thermal properties of peat soil}

The heat capacity of dry peat was set to $0.58\left[\mathrm{M} \mathrm{J} \mathrm{m}^{-3} \mathrm{~K}^{-1}\right]$ (Bonan, 2002), while heat capacity for wet peat was computed based on the volume fractions of peat and water and the temperature (Eq. 2). The thermal conductivities for frozen and thawed peat $\left(\lambda_{\mathrm{f}}\right.$ and $\left.\lambda_{\mathrm{t}}\right)$ were computed using the empirical relationships found by O'Donnel et al. (2009):

$\lambda_{\mathrm{f}}=0.0055 \theta \cdot 100+0.0141$

$\lambda_{\mathrm{t}}=0.005 \theta \cdot 100+0.04$

where $\theta$ is the water content as a fraction of saturation.

The thermal properties of peat soil are therefore largely controlled by the water content in the peat soil and the position of the water table, both of which depend on the type of peatland (bog, fen), and microtopographical features. These hydrological conditions provide an important control on physical, chemical, and biological processes in peatlands (Weiss et al., 2006) and the position of the water table can both promote and hinder freezing in peatlands (Kingsbury and Moore, 1987) but very few measurements for water table or soil moisture in boreal peatlands exist (Weiss et al., 2006). In addition, the relationship between water table depth and soil moisture in the layers above the water table is site specific and difficult to generalize over a large domain.

We conceptually divided the peat soil column into fibric, mesic, and humic peat for which different levels of soil moisture $\theta$ were assumed, and the depth of those layers depends on the position of the water table in the peat column. Soil moisture for the fibric and mesic layers were set at 0.2 and 0.5 respectively and the humic peat layer was assumed to be fully saturated.

The position of the water table in peatlands is relatively stable over time (Frolking et al., 2009). Generally, the water table is deeper in bogs and higher in fens (Zoltai et al., 1998), which are the two dominant forms of peatlands in the Northern Hemisphere (Rydin and Jeglum, 2006; St-Hilaire et al., 2008). For example, Tarnocai (2006) estimates that bogs cover $67 \%$ of the Canadian peatlands, fens cover $32 \%$, and swamps and marshes combined cover $1 \%$.

Based on observations of the mean water table from a variety of boreal peatlands from Zoltai et al. (1998) we simulated soil temperatures in peatlands for two positions of the water table; a wet scenario with a water level at $0.07 \mathrm{~m}$, representing a fen, and a dry scenario with a water level at $0.30 \mathrm{~m}$, representing a bog. We assumed the water table to be constant throughout the simulation period. For both scenarios, the depth of the fibric peat layer was assumed to be at $30 \%$ of the water table depth. The different assumptions regarding the position of the water table and the depth of the soil layers are conceptually depicted in Fig. 1. 


\subsection{Peatland area and peat depth}

To partition the grid cells into a fraction occupied by peatlands and a fraction with mineral soils, we used the recently published Northern Circumpolar Soil Carbon Database (NCSCD; Tarnocai et al., 2009) which lists soil types and soil carbon content for some 140000 polygons in the circumpolar region. To estimate the extent of peatland in each $30 \mathrm{~min}$ grid cell, we aggregated the areas of histosol and histel (frozen histosol) soil types. The resulting total peatland area for Canada and Alaska was 1.38 million $\mathrm{km}^{2}$ in 2430 grid cells $-11 \%$ of the study area (Fig. 2). This area represents about one third to almost one half of the global peatland area north of $40^{\circ}$ latitude that was previously estimated to be around 3-4 million $\mathrm{km}^{2}$ (Matthews and Fung, 1987; Aselmann and Crutzen, 1989; Yu et al., 2010).

The total soil organic carbon (SOC) in histels and histosols in the NCSCD database was $165 \mathrm{PgC}$ for the study region. The depth of these peat soils can be computed by assuming a carbon density and a peat dry bulk density, both of which vary significantly spatially depending on local conditions. For example, Turunen et al. (2001) found carbon density of $50-55 \%$ and mean values of bulk density of $91 \mathrm{~kg} \mathrm{~m}^{-3}$ for west Siberian peatlands. Gorham (1991), based on extensive Canadian datasets, reported an average bulk density of $112 \mathrm{~kg} \mathrm{~m}^{-3}$ and a carbon density of $51.7 \%$ of dry mass. Turunen et al. (2002) found the average dry bulk density of Finnish geological mires to be $91 \mathrm{~kg} \mathrm{~m}^{-3}$ and Vitt et al. (2009) found that peat bulk density in Canada typically varies between $90 \mathrm{~kg} \mathrm{~m}^{-3}$ and $120 \mathrm{~kg} \mathrm{~m}^{-3}$ whereas Chason and Siegel (1986) found peat bulk density to vary between 60 and $140 \mathrm{~kg} \mathrm{~m}^{-3}$ in Northern Minnesota.

To estimate the peat depth in the peat fraction of each grid cell we assumed a uniform carbon density of $50 \%$ and peat bulk density of $100 \mathrm{~kg} \mathrm{~m}^{-3}$. The resulting average peat depth is $3.21 \mathrm{~m}$. Calculated peat depths were quite different for Alaska (generally around $0.6 \mathrm{~m}$ ) and Canada, which had much larger spatial variability and ranged from less than $0.5 \mathrm{~m}$ on the Western coast to several meters in the Hudson Bay Lowlands. The total volume of peat, calculated as the product of peat depth and peat area is $3480 \mathrm{~km}^{3}, 98 \%$ of which was in Canada (Fig. 2). In cases where our estimated peat depth was smaller than 30 or $40 \mathrm{~cm}$ (the minimum organic layer depth for organic soils to be considered peatlands in the US and Canada), we treated those as if there was only mineral soil with a thin organic layer. This affected only 29 grid cells in Canada and Alaska ( $\sim 1 \%$ of total number of grid cells with peatland).

\subsection{Climate data}

Daily time series of precipitation and air temperature for the period 2001-2100 were taken from the ECHAM 5 model (Roeckner et al., 2003) for the IPCC scenario A1B.
Simulated 20th century (20C3M) ECHAM5 air temperatures for the northern regions $\left(20-90^{\circ} \mathrm{N}\right)$ have been found to have the smallest bias out of all the models used in the IPCC AR4 assessment when compared to the 40 year ECMWF reanalysis (ERA40) data (Walsh et al., 2008) and was therefore chosen for the offline simulations of soil temperatures and permafrost. The original coarser resolution data was interpolated to $0.5^{\circ}$ grid cells using the NCAR NCL software (NCAR, 2011).

Air temperature in the northern regions is projected to increase more rapidly than in the other regions; the mean annual air temperature in the model domain increases from $-3.96^{\circ} \mathrm{C}$ for the first decade of the century to $-1.94{ }^{\circ} \mathrm{C}$ for the period $2041-2050$ and $+1.0^{\circ} \mathrm{C}$ for the last decade of the century. Much of the warming in mean air temperature is seen in the winter months whereas summer temperature over the entire model domain increases only slightly. Mean annual precipitation in the model domain increases from $784 \mathrm{~mm}(2001 / 2010)$ to $922 \mathrm{~mm}$ (2090/2100), representing an increase of nearly $18 \%$. This is a consistent pattern across many GCMs (Arctic Climate Impact Assessment, 2004; Meehl et al., 2007; Rawlins et al., 2010).

\section{Results}

\subsection{Model evaluation}

The GIPL model has been validated against ground temperature measurements in shallow boreholes in Alaska that represent a wide range of soil and vegetation characteristics (Romanovsky and Osterkamp, 2000; Nicolsky et al., 2009). In a complementary paper (Treat et al., 2011, in prep.) the model presented here has been tested against observed time series of daily measured soil temperature at different depths in a permafrost peatland site in Northwest Territories, Canada, and a permafrost site with a thick organic horizon in Alaska (Treat et al., 2010). The results showed generally a good agreement of observed and modeled soil temperatures.

The range in seasonal mean soil temperature is generally higher in mineral soils, in particular near the surface. The differences in modeled soil temperatures are generally smaller for deeper soil layers where the temperatures are governed by long-term variations in mean annual air temperatures rather than responses to seasonal variations in air temperature.

To further evaluate the model and the assumptions regarding the properties of mineral and peat soils we compared modeled active layer thickness (ALT) under contemporary (2001-2010) conditions with ALT measurements from 56 sites in Alaska and Canada, representing a wide range of soil, topographical, and climatic conditions, from the Circumpolar Active Layer Monitoring (CALM; Brown et al., 2000) program. The annual ALT measurements generally represent an average value from a sample grid of 121 points over an area of $1 \mathrm{ha}$ or $1 \mathrm{~km}^{2}$. ALT is typically measured by inserting 
a steel rod into the soil and recording the thawed soil depth. The maximum depth that can be measured is therefore limited by the length of the steel rod $(\sim 1.20 \mathrm{~m})$. As the period of observations in the CALM database varies for each station, we averaged annual values for the most recent 10 years and compared those values with the mean modeled annual ALT for the period 2001-2010.

ALT at a particular location depends on a number of factors including thermal properties of soil, vegetation, snow cover, soil moisture, and there is consequently a wide range of ALT observations across a spectrum of temporal and spatial scales (Brown et al., 2000) and within a single site (Hinkel and Nelson, 2003). For example, Wright et al. (2009) found the variability of the ALT in peatlands in northwestern Canada over distances of less than one meter to be correlated with lateral water flow converging to frost table depressions, a process that is not taken into account in our modeling approach. Smith at al. (2009) showed variations around the mean for one site of around $50 \%$. Nelson et al. (1997) reported extreme local variations in ALT, based on terrain and soil moisture conditions; for example they found a difference in ALT of $50 \%$ between an acidic and non-acidic tundra site. Similarly, differences in the terrain lead to differences in observed ALT of $20 \mathrm{~cm}$ from one observation grid $\left(1 \mathrm{~km}^{2}\right)$ to the next. ALT also varies from one year to the next.

Despite these inconsistencies in the spatial and temporal resolution of observed and modeled data that make a formal comparison difficult, our model generally reproduces the observed range of ALT well; observed average ALT ranges from 0.30 to $1.34 \mathrm{~m}$ (mean of $0.61 \mathrm{~m}$ ) whereas the modeled ALT thickness ranges from 0.36 to 1.04 (mean of $0.65 \mathrm{~m}$ ) for mineral soils, and from 0.16 to $0.42 \mathrm{~m}$ (mean of $0.31 \mathrm{~m}$ ) for dry peat and from 0.18 to 0.54 (mean of $0.35 \mathrm{~m}$ ) for wet peat. Data on soil temperatures or the composition of soil throughout the soil column are generally not available for CALM sites, so the depth of the organic layer is not known. Nonetheless, Brown et al. (2000) report that CALM data indicate that the insulating properties of organic soil generally lead to smaller interannual variations in ALT and to a shallower active layer depth, consistent with the simulations.

\subsection{Trends in the timing and distribution of snow cover}

Despite the projected increase in precipitation (see Sect. 2.4), the annual amount of snowfall slightly decreases over the entire model domain as a result of warming air temperatures. The mean annual values of snow depth show a significantly decreasing trend for most of the model domain: increasing trends are only seen in small regions around Northeast Alaska and in the polar regions of Canada. In areas with peatlands, the mean annual snow depth decreases on average by $0.72 \mathrm{~mm} \mathrm{a}^{-1}$ over the simulation period.

We defined the snow season as the period when the ground is covered with a snow cover of an average depth of more than $1.0 \mathrm{~cm}$ over a period of five days.
The domain-mean onset of the snow season is 5 October for the period 2001-2010, but by the end of the century the domain-mean onset is 11 October. The domain-mean date for snowpack disappearance is 18 May for 2001-2010; it occurs 10 days earlier by the end of the century (8 May). Combined, the period when the ground is covered with snow decreases by around 16 days by the end of the century, representing a decrease in the snow season length of about $7 \%$.

\subsection{Trends in soil moisture}

Both the heat capacity and the thermal conductivity of soil increase with increasing soil moisture (Eqs. 5 and 6). Increasing soil moisture in the future could therefore lead to faster responses of soil temperatures to changes in air temperature (as a result of higher thermal conductivity), resulting in an increased warming of the soil. Increased heat capacity, on the other hand, leads to a slower response of soil temperatures, in particular if temperatures are low and around the freezing point (Eq. 1) and large quantities of heat need to be added/removed for the thaw/freeze phase change (Boike et al., 2009). The large increase in precipitation in the model domain (Sect. 2.4) was partly offset by increased evapotranspiration as a result of higher temperatures, and the resulting increases in annual average values of simulated soil moisture were small. Average annual values of mineral soil moisture increased from $61 \%$ during 2001/2010 to $62 \%$ in 2041/2050 and $64 \%$ in $2091 / 2100$.

\subsection{Trends in the frost-free season}

We defined the onset of the thaw season as the first day when the soil temperature (averaged over a period of five days) at a depth of $5.0 \mathrm{~cm}$ rises above $0{ }^{\circ} \mathrm{C}$ and the end of the thaw season as the day when the averaged soil surface temperature drops below $0{ }^{\circ} \mathrm{C}$. The spatial distribution of the onset of the frost-free season in the model domain follows the temperature gradient and varies from March in the southernmost parts of Canada to the end of May/early June in northern Canada. Averaged over the model domain, the frost-free period under contemporary conditions starts on 14 April and lasts until 26 September. By the end of the century, the onset will occur 25 days earlier (22 March), with the end of the frost-free period shifting from 26 September to 18 October (Table 2 and Fig. 3). The changes in the frost free season in areas covered with peatlands show a very similar pattern (Fig. 4). The differences in peat soils and mineral soils are caused both by the different thermal properties and the spatial distribution of peat soil in relation to the entire model domain (Fig. 2); peat soils are concentrated in the southern (and warmer) regions of the model domain.

The frost-free season increases from 174 to 214 days for the entire model domain, and for peatland areas from 179 to 218 days (Table 2). These increases represent a lengthening of the biologically active period of $25 \%$ and $22 \%$. On 
Table 2. Domain mean annual start dates, end dates (Julian Day and date) and length (days) of the frost-free period in peatlands and mineral soils for first, mid, and last decades of 21 st century.

\begin{tabular}{|c|c|c|c|}
\hline & $2001 / 2010$ & $2041 / 2050$ & $2091 / 2100$ \\
\hline \multicolumn{4}{|c|}{ Peat soil } \\
\hline Thaw day & $106(8 \mathrm{Apr})$ & 97 (28 Mar) & 79 (12 Mar) \\
\hline Freeze-up day & 285 (14 Oct) & 292 (24 Oct) & 297 (3 Nov) \\
\hline Thaw season Length & 179 & 195 & 218 \\
\hline \multicolumn{4}{|c|}{ Mineral soil } \\
\hline Thaw day & 110 (14 Apr) & 101 (5 Apr) & 85 (22 Mar) \\
\hline Freeze-up day & 284 (26 Sep) & 291 (5 Oct) & 299 (18 Oct) \\
\hline Thaw season Length & 174 & 190 & 214 \\
\hline
\end{tabular}

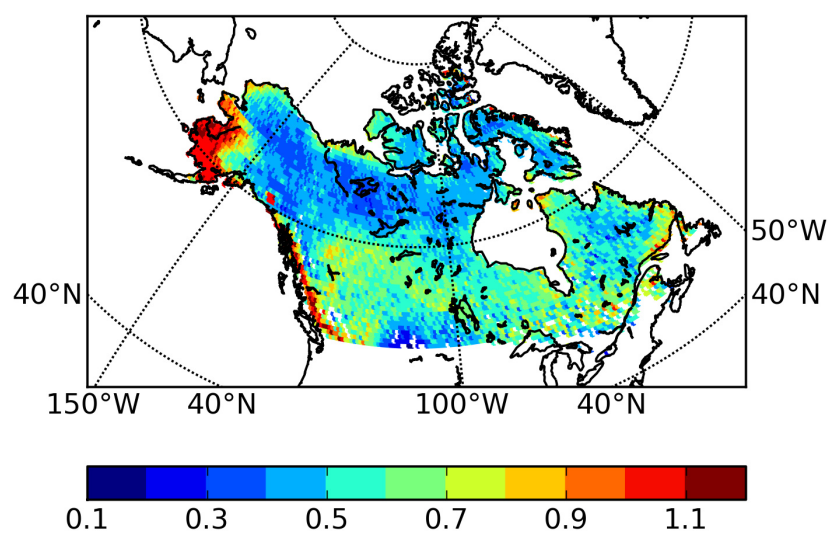

Fig. 3. Significant trends [days $\mathrm{a}^{-1} \mathrm{a}^{-1}$ ] in freeze-free period in the model domain, derived from the soil surface temperature at $0.05 \mathrm{~m}$ for 2001-2100.

average, the increase is caused by both an earlier thawing date as well as a later freeze date; the freeze date is generally more variable across the model domain (Fig. 4). The increases in the thawing period length are largest in southern Alaska, and eastern and western Canada and smallest in northern Canada, where the thawing season is shortest (Fig. 3).

\subsection{Geography of peatlands and permafrost}

\subsubsection{Contemporary conditions}

Our modeled estimate of the peatland area that is underlain by permafrost is based on the assumption of negative temperatures for at least 24 consecutive months; a grid cell can therefore be either classified as (continuous) permafrost or as non-permafrost. The estimated permafrost area varies greatly with the reference depth at which modeled temperatures are evaluated (Table 4). For a water level in peatlands of $0.30 \mathrm{~m}$ (the dry scenario) the area of peatlands that is underlain by

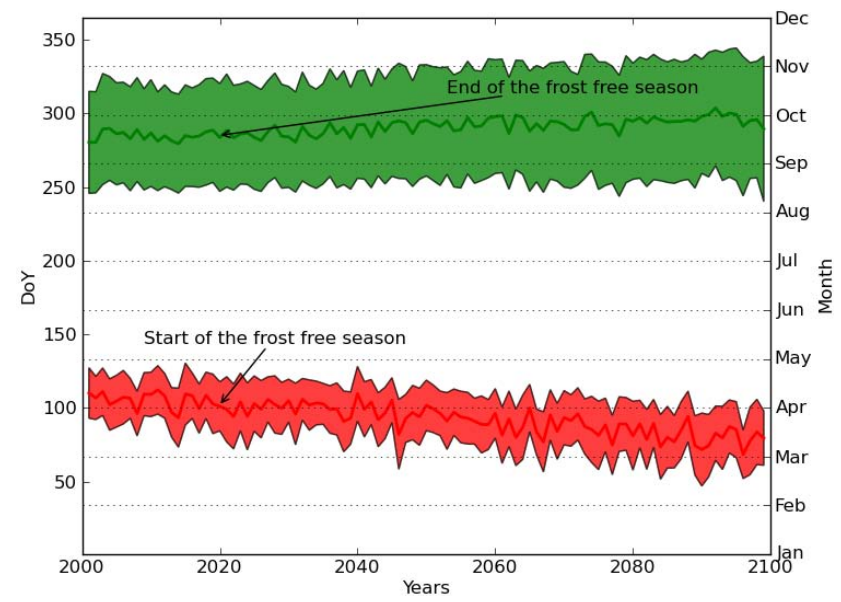

Fig. 4. Time series of the mean simulated start and end of the freezing period at the surface for grid cells with peat soils and one standard deviation around the mean.

permafrost varies from $43 \%$ of the total area at $0.5 \mathrm{~m}$ to $72 \%$ at $5.0 \mathrm{~m}$. For the wet peat scenario (water level at $0.07 \mathrm{~m}$ ), these estimates vary between 33 and $72 \%$.

The higher thermal conductivity and consequently more variable active layer dynamics lead to a wider range of permafrost areas in mineral soils. The mineral soil underlain by permafrost ranges from $17 \%$ at the surface $(\leq 0.5 \mathrm{~m}$ depth) to more than $63 \%$ at $5.0 \mathrm{~m}$ depth.

The spatial distribution of ALT for dry peat, wet peat and mineral soil in the model domain generally follows the climate gradient but shows some regional variation that reflects the depth of peat, the distribution of the thin organic layer on mineral soils, and the composition of the soil that impact thermal properties of soil (Fig. 5).

\subsubsection{Future projections of the permafrost area}

Warming air temperatures generally increase the active layer thickness and consequently decrease the area of mineral and peat soil underlain by permafrost depending on the reference depth used to define permafrost areas. The modeled thickness of the active layer significantly increases but is strongly dependent on the composition of the soil (peat versus mineral soil) and the moisture status in peat soils (high water table versus low water table). Under the dry peat scenario (water level at $0.30 \mathrm{~m}$ ), the ALT for near surface soil layers (depth $<2.0 \mathrm{~m}$ ) increases from $0.36 \mathrm{~m}$ for the first decade of the century to $0.44 \mathrm{~m}$ at the end of the century, representing an increase of $22 \%$. For comparison, the mineral soil ALT in grid cell with peat increases from 0.70 to $0.93 \mathrm{~m}(32 \%)$. Figure 5 shows the areas with an ALT of less than $2.0 \mathrm{~m}$ and indicates an almost complete disappearance of surface permafrost areas for mineral soil by 2100 , whereas permafrost in peatlands is more persistent with smaller changes in ALT and permafrost area. 
Dry Peat

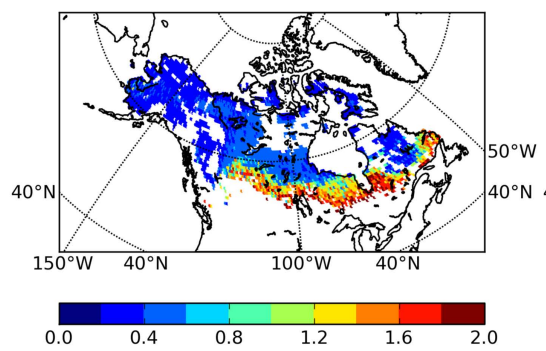

$2001 / 2010$

$2041 / 2050$
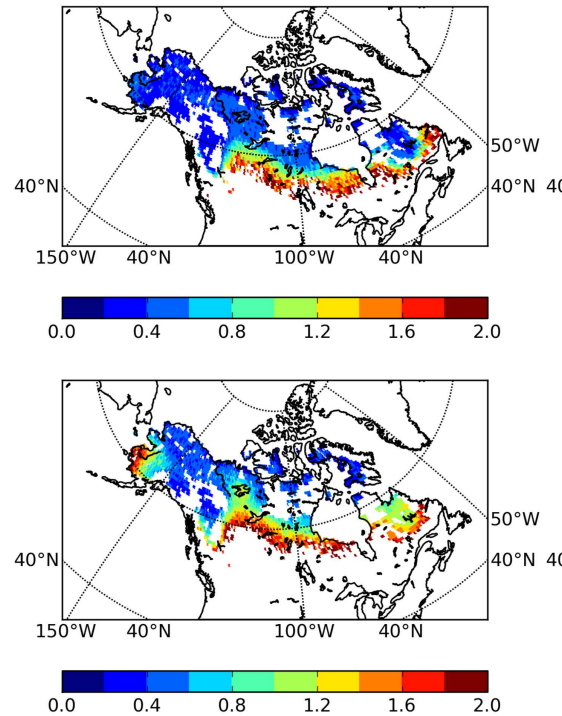

Wet Peat
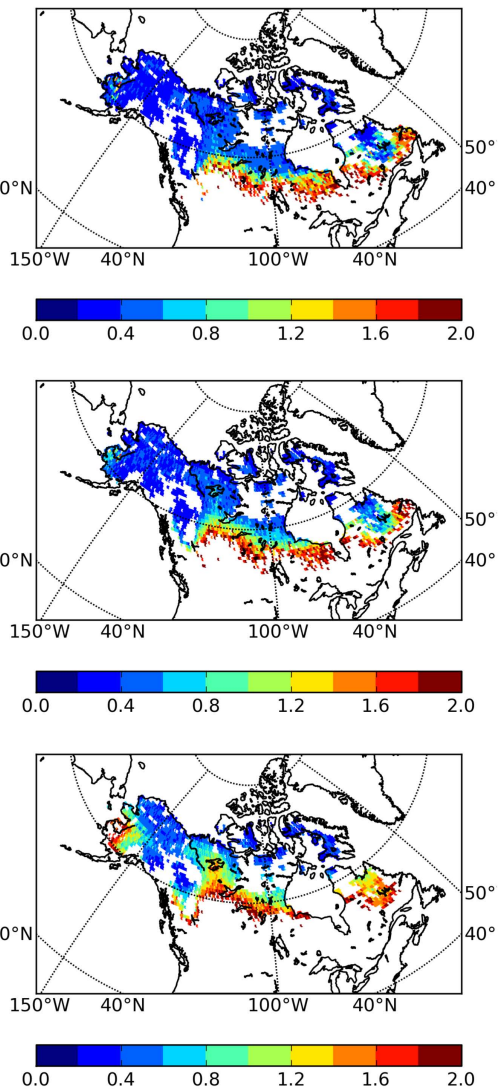

Mineral Soil
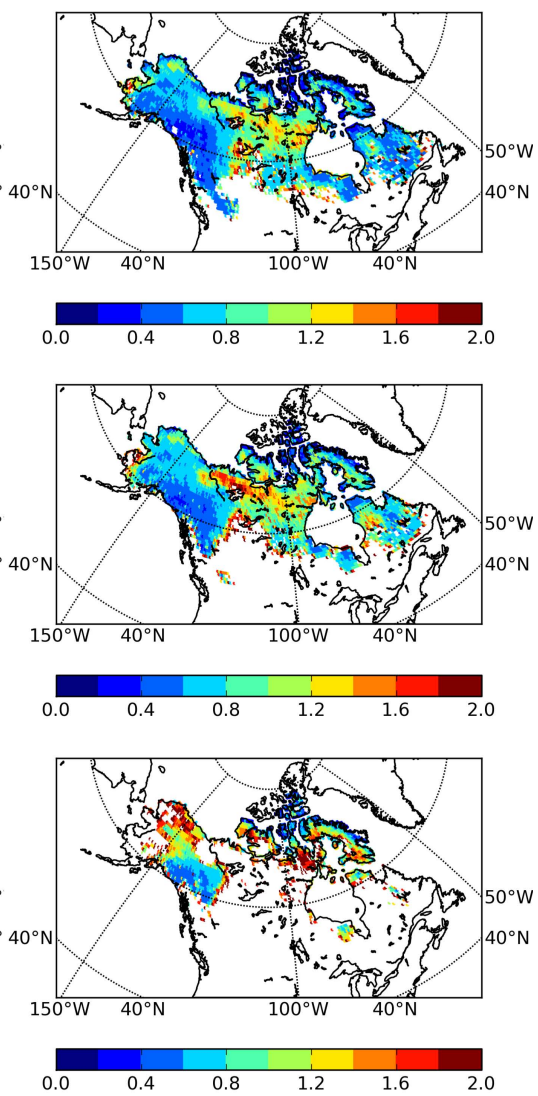

Fig. 5. Modeled average ALT [m] under contemporary (2001/2010), mid-century (2041/2050) and end-century (2091/2100) climate conditions for dry peat (left), wet peat (middle) and mineral soils (right). ALT $>2.0 \mathrm{~m}$ is masked out.

The projected deepening of the ALT has large implications for the area classified as permafrost depending on the reference soil depth. Compared to contemporary conditions, the area of peatlands underlain by permafrost at $0.5 \mathrm{~m}$ depth declines from $43 \%$ to $33 \%$ of the total peatland area by the middle of the next century and to $\sim 14 \%$ by 2100 (Table 4 and Fig. 6). In mineral soils, the surface permafrost $(\leq 0.5 \mathrm{~m}$ depth) area decreases at a much faster rate than in peat soils, and will almost completely disappear by 2100 . Near surface permafrost $(2.0 \mathrm{~m})$ in mineral soils decreases by $\sim 60 \%$ over the century. When considering deeper soils, the permafrost in peatland areas is very stable; the permafrost area at $5 \mathrm{~m}$ depth is only reduced by $1 \%$ by the end of the century whereas the mineral soil area underlain by permanently frozen soil at $5 \mathrm{~m}$ decreases by $\sim 20 \%$ by the end of the century.

\subsubsection{Future predictions of seasonally-thawed soil volume}

We compute the maximum seasonal thawed volume of peat soil, mineral soil, and surface organic horizon each year as the product of the simulated ALT in peatlands or mineral soils and the area of peat and mineral soils. If the ALT is deeper than the peat or mineral soil or surface organic layer depths (Sect. 2.3), these depths are used rather than ALT to calculate thawed volumes.

As the ALT is deeper than the thin organic layer overlying mineral soil almost everywhere under contemporary climate conditions, changes in the maximum thawed organic layer volume by 2100 are negligible (Table 5). The maximum volume of unfrozen mineral soil, however, increases from $53 \%$ of the total soil volume under contemporary conditions to more than $80 \%$, representing an increase in thawed volume of more than $50 \%$ (Fig. 6 and Table 5).

Despite the moderate decrease in the permafrost areas in peat soils (Sect. 3.5.2), changes in the maximum thawed volume of peat as a result of a deepening active layer are also quite significant. Under contemporary conditions (20012010), $1850 \mathrm{~km}^{3}$ of peat $(45 \%)$ are unfrozen in the dry peat scenario. This unfrozen volume of peat for the dry scenario increased to $2056 \mathrm{~km}^{3}$ by 2050 and to $2511 \mathrm{~km}^{3}$ ( $64 \%$ of the peat volume) in the last decade of the century. The thawed volume of peat under the wet scenario is $\sim 5 \%$ larger. The increase in maximum thawed volume of peat by $661 \mathrm{~km}^{3}$ 


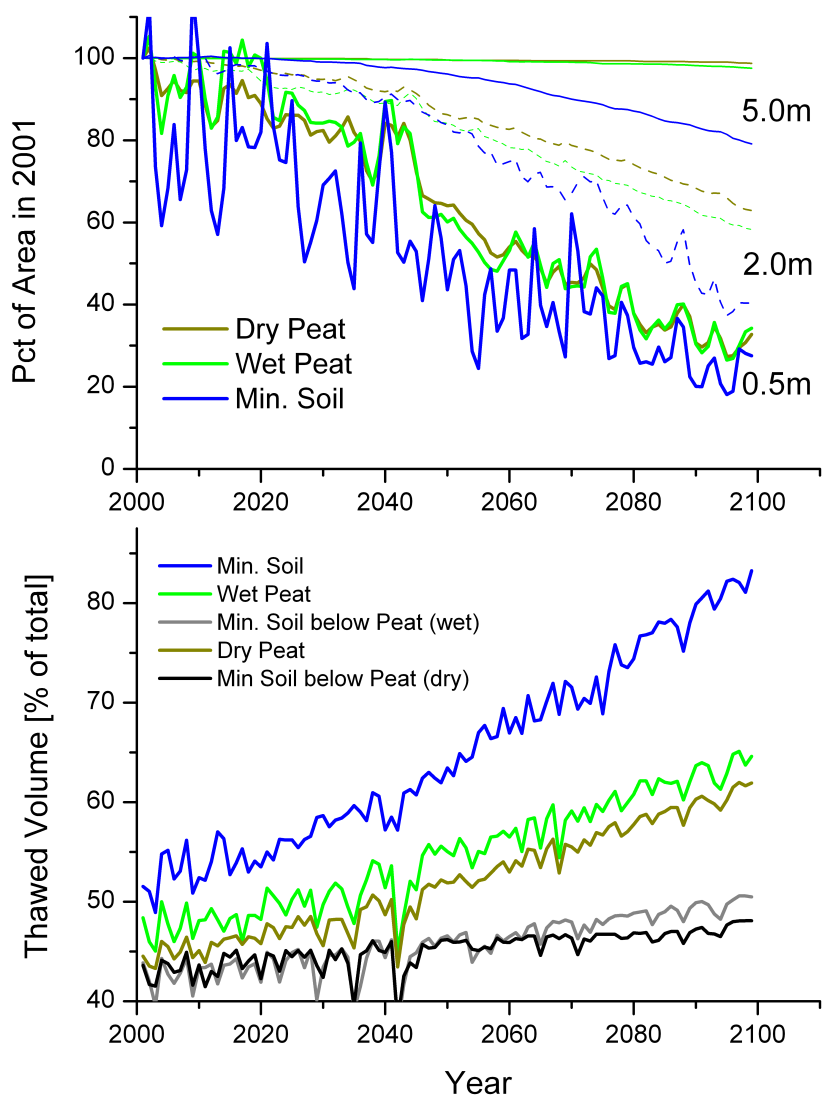

Fig. 6. Areas underlain by permafrost at different depth for dry and wet peat and mineral soil relative to 2001 (top; see Table 5 for absolute values) and time series of thawed soil volume as percentage of the total volumes (bottom; see Table 6 for absolute values)

represents $\sim 20 \%$ of the estimated peat volume in Canada and Alaska and can potentially have large implications for the soil carbon balance in the region.

\section{Discussion}

\subsection{Climate conditions and soil thermal regimes}

\subsubsection{Snow}

The timing and magnitude of snowfall, the resulting snow depth, and the length of the snow season (the number of days with a significant snow pack on the ground) are some of the most important factors influencing the response of soil temperature to variations in air temperature (Stieglitz et al., 2003; Zhang et al., 2008a; Jorgenson et al., 2010; Lawrence and Slater, 2010) and therefore ultimately impact biogeochemical cycling rates in the soil (Schimel et al., 2004). Lawrence and Slater (2010) estimate that 50-100\% of the soil temperature changes by the end of the last century could be caused by variations in the snow state.
Generally, the response of soil temperatures to air temperatures is dampened the deeper the snow pack and a thinner showpack leads to colder winter soil temperatures. Longterm modeling results for Canada show a decreasing snow pack for the period 1850-2100 and suggest that the rate of increase in ground soil temperatures is $1-2^{\circ} \mathrm{C}$ smaller than that of air temperature and that the rate of permafrost degradation is smaller than based on the changes in air temperature alone (Zhang et al., 2008a).

Changes in the length of the snow season can lead to an increased warming or cooling of the ground depending on when the snow season is shortened. A delayed offset of the snow season (earlier melt) increases the heat flux into the soil whereas a delay of the snow season onset can lead to both warming and cooling of the ground depending on the temporal patterns of air temperature and snowfall (Lawrence and Slater, 2010). If the delay is due to warmer air temperature and a delayed transition to below-freezing air temperatures, the result is a warming effect. If the delayed onset is primarily a result of changed precipitation patterns and less snow, the soil is not as insulated from colder air temperatures and the result will be lower soil temperatures.

Our modeled decrease in the mean annual snow depth is consistent with climate model projections across the Northern Hemisphere (Arctic Climate Impact Assessment, 2004; Zhang et al., 2008b; Lawrence and Slater, 2010) and with observed trends from measurements conducted in the last decades (Dyer and Mote, 2006). A lengthening of the snow free period between 3.1 and 6.4 days for the last 30 years has been observed using satellite data for the period 1972-2000 in North America (Dye, 2002). Our results indicate that the extension of the snow free season of 16 days by the end of the century is largely caused by an earlier melting date, resulting in less insulation of the soil from colder temperatures and consequently more heat flux into the soil. The shallower snowpack leads to less insulation of the soil from cold air during the winter months, resulting in colder soil temperatures in winter that partly offset the increases in air temperature.

\subsubsection{Soil temperatures and active layer thickness}

Warmer soil temperatures resulting in a deepening of the ALT have been widely observed in the Northern Hemisphere. Permafrost temperature at $20 \mathrm{~m}$ depth has increased by 1 to $2{ }^{\circ} \mathrm{C}$ in northern Eurasia during the last 30 to 35 years (Romanovsky et al., 2010). This observed increase is very similar to what has been observed in Alaska and Canada (Romanovsky et al., 2010; Smith et al., 2010) where the warming varies between locations, but is typically from 0.5 to $2^{\circ} \mathrm{C}$. In the last 30 years, an increase of temperatures in deeper layers of permanently frozen soils observed in the Russian North and Alaska has resulted in the thawing of permafrost in natural, undisturbed conditions in areas close to the southern 
boundary of the permafrost zone. This warming occurred predominantly between the 1970s and 1990s.

Warming at the surface increases the ALT that controls a number of hydrological processes and determines the plant root depth, the access to nutrients in the soil, and therefore impacts biogeochemical processes in the soil (Shiklomanov et al., 2007). Zhang et al. (2008b) reported an increase in the ALT by $14-30 \%$ from the 1990s to the 2090s in the permafrost region in Canada, depending on the climate forcing. For the entire Northern Hemisphere, Anisimov et al. (1997) reported an increase in ALT of $20-30 \%$.

These changes lead to changes in the areas classified as permafrost that is often used to report changes in the soil temperature as a result of warming air temperatures. Studies on the impact of global warming on soil conditions often report the changes in area underlain by permafrost (Lawrence and Slater, 2008; Zhang et al., 2008b). Consistent with those projections, our results suggest that ALT in peat soils increase by $22 \%$ and, in mineral soils in the same domain, by $32 \%$.

\subsubsection{Permafrost areas and thawed volumes}

To assess the contemporary geography of peatlands and permafrost areas in the model domain we used the permafrost classification of Brown et al. (2001), that subdivided the Northern permafrost region on the basis of the proportion of the ground that is actually frozen to various degrees (Hegingbottom, 2002) into continuous ( $>90 \%$ permafrost), discontinuous (50-90\%), sporadic (10-50\%), and isolated (0$10 \%)$ permafrost. Assuming the actual extent of permafrost in each class is equal to the midpoint of the reported range (for example $30 \%$ for areas classified as sporadic), a total area of $418300 \mathrm{~km}^{2}(30 \%)$ of peatlands is underlain by permafrost under contemporary conditions (Table 3 ) based on this present-day reference map (Fig. 2). Two thirds of the peatland areas are not permanently frozen under contemporary conditions. These results are comparable with our modeled results that are based on below zero temperatures at a given depth for a period of at least 2 years (Sect. 3.5.1) and are consistent with the $37 \%$ of Canadian peatlands in permafrost areas estimated by Tarnocai (2006).

As the definition of permafrost is independent of the depth at which the layer is frozen and permafrost can be up to several hundred meters deep, a comparison of "permafrost areas" from models that simulate the temperature profile to very different depths might be misleading and approaches to determine permafrost areas based on model results consequently vary. For example, in Zhang et al. (2008b), a grid cell contained permafrost in a given year if the temperature in any layer in the soil column (modeled to a depth of $120 \mathrm{~m}$ ) was never above freezing; the projected decline of those areas in Canada was $16-20 \%$ by the 2090s. Lawrence et al. (2008) followed the approach of Zhang et al. (1999) and defined permafrost as areas with a temperature below $0^{\circ} \mathrm{C}$ for two or more consecutive years and projected a dramatic decline of
Table 3. Contemporary geography of peatlands and permafrost extent in Alaska and Canada. Percentages relative to the total peatland area in Alaska and Canada (1.40 million $\left.\mathrm{km}^{2}\right)$. Permafrost classification from Brown et al. (2001).

\begin{tabular}{lcccc}
\hline $\begin{array}{l}\text { Permafrost } \\
\text { Extent }\end{array}$ & $\begin{array}{c}\text { Area } \\
{\left[\mathrm{km}^{2}\right]}\end{array}$ & $\begin{array}{c}\text { Assumed } \\
\text { actual } \\
\text { coverage }[\%]\end{array}$ & $\begin{array}{c}\text { Actual } \\
\text { Area } \\
{\left[\mathrm{km}^{2}\right]}\end{array}$ & $\begin{array}{c}\text { Percent } \\
\text { of total } \\
\text { peatland } \\
\text { area }\end{array}$ \\
\hline Continuous & 210000 & 95 & 200000 & 15 \\
Discontinuous & 200000 & 70 & 140000 & 10 \\
Sporadic & 250000 & 30 & 74000 & 5 \\
Isolated & 200000 & 5 & 10000 & 1 \\
\hline Sum & 850000 & & 420000 & 31 \\
\hline
\end{tabular}

$\sim 90 \%$ in the "near surface" (top $3.5 \mathrm{~m}$ ) permafrost area by the end of the century.

From a biogeochemical perspective, the classification of areas as permafrost based on some (arbitrary) soil depth can be misleading as it ignores the volume of (peat) soil that is actually thawed on top of the permafrost table and could potentially interact with the atmosphere and hydrosphere, as well as the change the carbon budget of the soil should previously frozen soil become permanently thawed. This volume can be compared to the total volume and the volume of previously frozen (and mostly inert) soil volumes.

Our results indicate that despite a widespread degradation of permafrost and a rapid decrease in the area classified as permafrost, the thawed volume of peat increases by only $20 \%$ by the end of the century (Table 5). Additional thawing of the thin organic layer is negligible because the deepening of the ALT will affect mostly deeper mineral soils while the thin organic layer thaws every season (Anisimov, 2007).

\subsubsection{Frost free season}

Between 2000 and 2100, we found an increase in frost-free season length of $\sim 40$ days in peatlands across North America, most of which is caused by an earlier thaw in the spring.

These estimates are consistent with projected increases in the growing season and with lengthening of the growing season that has already been observed in northern latitudes. A recent increase in growing season length in northern latitudes has been found by others (Euskirchen et al., 2006; Smith et al., 2004). Euskirchen et al. (2006) found a rate of increase in the growing season of 0.38 days $\mathrm{a}^{-1}$ from 1960-2000 and predicted an increase of 35 days between 2000-2100. 
Table 4. 10-year average peatland areas underlain by permafrost at different depths ( 2 significant figures). Percentages are computed relative to total peatland area $\left(1.41\right.$ million $\left.\mathrm{km}^{2}\right)$ and mineral soil area $\left(11\right.$ million $\left.\mathrm{km}^{2}\right)$

\begin{tabular}{|c|c|c|c|c|c|c|c|}
\hline \multirow[b]{2}{*}{ depth } & & \multicolumn{2}{|c|}{$2001 / 2010$} & \multicolumn{2}{|c|}{$2041 / 2050$} & \multicolumn{2}{|c|}{$2091 / 2100$} \\
\hline & & Area $\left[\mathrm{km}^{2}\right]$ & $\%$ & Area $\left[\mathrm{km}^{2}\right]$ & $\%$ & Area $\left[\mathrm{km}^{2}\right]$ & $\%$ \\
\hline \multirow[t]{3}{*}{$0.5 \mathrm{~m}$} & Peat dry & 610000 & 43 & 470000 & 33 & 200000 & 14 \\
\hline & Peat Wet & 490000 & 34 & 360000 & 26 & 160000 & 11 \\
\hline & Mineral Soil & 1900000 & 17 & 1200000 & 11 & 540000 & 5 \\
\hline \multirow[t]{3}{*}{$1.0 \mathrm{~m}$} & Peat dry & 710000 & 50 & 600000 & 42 & 330000 & 24 \\
\hline & Peat Wet & 630000 & 44 & 540000 & 39 & 260000 & 19 \\
\hline & Mineral Soil & 5600000 & 48 & 4400000 & 38 & 1500000 & 13 \\
\hline \multirow[t]{3}{*}{$2.0 \mathrm{~m}$} & Peat dry & 970000 & 69 & 880000 & 62 & 640000 & 45 \\
\hline & Peat wet & 860000 & 61 & 760000 & 54 & 520000 & 37 \\
\hline & Mineral soil & 7200000 & 62 & 6300000 & 54 & 2900000 & 25 \\
\hline \multirow[t]{3}{*}{$5.0 \mathrm{~m}$} & Peat dry & 1000000 & 72 & 1000000 & 72 & 1000000 & 72 \\
\hline & Peat wet & 1000000 & 72 & 1000000 & 72 & 1000000 & 71 \\
\hline & Mineral soil & 7300000 & 63 & 7100000 & 61 & 5900000 & 51 \\
\hline
\end{tabular}

Table 5. Volumes of thawed mineral and peat soil for different time slices and percentages of total soil volume (2 significant figures).

\begin{tabular}{|c|c|c|c|c|c|c|}
\hline & \multicolumn{2}{|c|}{$2001 / 2010$} & \multicolumn{2}{|c|}{$2041 / 2050$} & \multicolumn{2}{|c|}{$2091 / 2100$} \\
\hline & $\begin{array}{r}\text { Volume } \\
{\left[\mathrm{km}^{3}\right]}\end{array}$ & $\%$ & $\begin{array}{r}\text { Volume } \\
{\left[\mathrm{km}^{3}\right]}\end{array}$ & $\%$ & $\begin{array}{r}\text { Volume } \\
{\left[\mathrm{km}^{3}\right]}\end{array}$ & $\%$ \\
\hline \multicolumn{7}{|c|}{ Uplands } \\
\hline Organic Layer & 1200 & 100 & 1200 & 100 & 1200 & 100 \\
\hline Mineral soil & 20000 & 53 & 23000 & 61 & 30000 & 81 \\
\hline \multicolumn{7}{|c|}{ Peatlands } \\
\hline Peat soils, wet & 2000 & 47 & 2200 & 50 & 2600 & 64 \\
\hline Peat soil, dry & 1900 & 45 & 2100 & 50 & 2500 & 61 \\
\hline Mineral soil (below wet peat) & 1500 & 43 & 1600 & 45 & 1700 & 50 \\
\hline Mineral soil (below dry peat) & 1500 & 43 & 1500 & 44 & 1700 & 47 \\
\hline
\end{tabular}

\subsection{Implications for carbon cycling}

The projected lengthening of the frost free period can have profound impacts on biogeochemical processes and the cycling of nitrogen $(\mathrm{N})$ and carbon $(\mathrm{C})$.

For example, longer thaw seasons could change the $\mathrm{N}$ dynamics in arctic watersheds (Yano et al., 2010), while warmer winters increase the rates of $\mathrm{N}$ mineralization (Schimel et al., 2004). A longer growing season may increase the uptake for $\mathrm{CO}_{2}$ (photosynthesis) but the effect on the net $\mathrm{C}$ balance depends on the hydrological conditions and the vegetation characteristics of the ecosystems considered (Strack et al., 2008). Lafleur and Humphreys (2008) observed higher $\mathrm{CO}_{2}$ uptake at a low-arctic site in the Northwest Territories during a year with an early spring (snowmelt occurred 3 weeks earlier than other years) and warmer air and soil temperatures, as compared with the other years in the study. A synthesis of boreal and temperate eddy correlation sites showed that the gains in productivity due to a longer growing season were partly compensated by increased respiratory losses, and that the response of fluxes to longer growing season depends on the characteristics of the vegetation, with deciduous forests being more sensitive than evergreen forests (Piao et al., 2007). Richardson et al. (2010) show that respiration increases more than productivity when the growing season is longer in the fall, and vice-versa in the spring. Euskirchen et al. (2006) found that increases in growing season length were correlated with increases in net ecosystem productivity, and vegetation $\mathrm{C}$. Often, labile $\mathrm{C}$ from deeper in the soil profile has been protected from decomposition by 
permafrost and is quickly mineralized with temperature increases following permafrost thaw (Zimov et al., 2006). Increasing soil temperatures, and the deepening of the active layer as a result of increasing air temperatures and changing snow dynamics will have implications for the cycling of carbon in peatlands and for the fluxes of carbon to the atmosphere and to the hydrosphere, as biogeochemical processes in peatlands are partly controlled by the freeze/thaw state of the (peat) soil.

The net effect of warming will depend on the balance of increased respiration and productivity (Schuur et al., 2009; Dorrepaal et al., 2009) as a result of warmer soils, and increased export of dissolved organic carbon (DOC) in rivers and streams in catchments with thawed peatlands (Frey and Smith, 2005).

Assuming that peat soils contain $50 \%$ of carbon, a bulk density of $100 \mathrm{~kg} \mathrm{~m}^{-3}$ (Sect. 2.3), and a uniform distribution of this carbon with depth, our estimate of an additional volume of peat of $670 \mathrm{~km}^{3}$ that would be thawed by $2100 \mathrm{im}$ plies that an additional $33 \mathrm{Pg}$ of carbon would be thawed. Carbon concentrations in mineral soils show a much higher range than those in peat soils. The additional amount of thawed carbon from mineral soils can therefore only be estimated with large uncertainties. Turunen and Moore (2003) found mean concentrations of $\mathrm{C}$ in mineral subsoils beneath peat in central Finland. Slightly higher values were reported by Hossain et al. (2007) for Northern Canada.

Assuming a mean concentration of $\mathrm{C}$ in mineral soils of $5 \mathrm{~kg} \mathrm{~m}^{-3}$ (a mean value for mineral subsoils beneath peat in central Finland found by Turunen and Moore, 2003), the additional volume of thawed mineral soils $\left(10700 \mathrm{~km}^{3}\right.$; Table 5) contains $53 \mathrm{Pg}$ of carbon. An additional $\sim 1 \mathrm{Pg}$ of $\mathrm{C}$ are contained in thawing mineral soils under (wet) peatland soils. The total amount of thawed carbon $(87 \mathrm{Pg}$ ) represents $\sim 8 \%$ of the entire carbon pool in the upper three meters of the soil the Northern Hemisphere, estimated to be around $1024 \mathrm{Pg}$ (Tarnocai et al., 2009). If we assume the same distribution of carbon with depth and a similar response of soil temperature ( $\sim 20 \%$ increase in the thawed peat volume) to warming in the Eurasian peatlands, an additional $\sim 32 \mathrm{Pg}$ of the estimated $163 \mathrm{Pg}$ stored in Eurasian peatlands (Tarnocai et al., 2009) could become biogeochemically active.

C processes are not only controlled by the transition of freeze/thaw but also by the temperatures alone, both in the subzero and above zero range. The warming of the soil even at temperatures below zero can have profound effects on the decomposition and production processes and thus the overall carbon balance of the peatlands (Gedney et al., 2004; Schuur et al., 2008; Carrasco et al., 2006), although the sensitivity of soil organic carbon (SOC) decomposition to soil temperature has recently been found to be scale dependent and lower on the global scale than expected from field experiments (Ise et al., 2008).
Winters and frozen-season processes are important for both the soil temperatures and the soil $\mathrm{C}$ balance. In addition to changes in permafrost degradation due to increased snowpack (Christensen et al., 2004; Payette et al., 2004; Stieglitz et al., 2003), Osterkamp (2005) found larger increases in permafrost soil temperatures during the winter than the summer. The duration of the thawed season at depth has significant implications for the annual C flux; Schimel et al. (2006) found that deeper, unfrozen mineral soil accounted for $50 \%$ of the daily $\mathrm{CO}_{2}$ production at sites in Alaska, and nearly $100 \%$ of $\mathrm{CO}_{2}$ production during the winter months in Alaska. Relatively large amounts of $\mathrm{CO}_{2}$ were still produced into December, when surface soil temperatures dropped below $-5^{\circ} \mathrm{C}$. The radiative forcing of peatlands can also be impacted by changes in the hydrological conditions: with wetter conditions, $\mathrm{CH}_{4}$ emissions increase (Turetsky et al., $2002,2007)$ and are very sensitive to changes in soil temperature (Turetsky et al., 2008).

\subsection{Uncertainties}

Our modeling approach, like other large scale efforts to simulate soil temperatures under changing conditions (Lawrence and Slater, 2005; Zhang et al., 2008b; Wania et al., 2009) is limited by a number of simplified assumptions and the omission of small scale processes that are not represented in the model. One of these shortcomings is the neglect of convective heat transport through infiltration from rainfall and snowmelt. Although heat conduction is the dominant heat transfer process in soils (Boike et al., 2009), infiltration accelerates the warming of the soil and could become more important in a wetter climate. Infiltration is a key process in arctic soils and is controlled mostly by the thaw status of the soil (Zhang et al., 2010), and can potentially lead to a delay in modeled spring thawing (Wania et al., 2009). The vertical transport of heat by infiltration of warmer rainwater or snowmelt is not currently considered in the model. However, experimental data suggests that the impact of soil moisture on the thermal regime is primarily through its influence on thermal conductivity and that heat advection plays a minor role (Wright et al., 2009).

The soil thermal regime is further influenced by the complex interaction between climate, topography, hydrology and vegetation, all of which cannot be adequately represented with the approach used here. For example, Jorgenson et al. (2010) reported differences in observed near-surface temperatures between boreal landscapes within similar climatic regions of $\sim 12^{\circ} \mathrm{C}$ based on those factors; our model takes into account hydrology in a simple way but ignores slope, aspect, and vegetation.

Further biases could arise from discounting the effects of vegetation that (1) limit the amount of solar radiation hitting the soil during the summer, and (2) impact the distribution and persistence of the snow cover (Smith and Riseborough, 2002). Anticipated changes in the vegetation as a result of 
warming air temperatures towards shrubbier vegetation could potentially provide more shading, change snowpack and alter heat flux into the soil as well (Sturm et al., 2005).

Uncertainties in our simulation are not only caused by uncertainties in the characterization of surface and subsurface parameters (Shiklomanov et al., 2007) but also by the climate forcing. Predictions of soil temperature depend on the forcing climate data and are subject to uncertainties in those data; the predicted soil temperatures can vary substantially (Anisimov and Reneva, 2009). For example, Anisimov et al. (2007) found that a $0.5-1.0^{\circ} \mathrm{C}$ difference the zonal mean air temperature could translate in differences in the projected permafrost area of 10-20\%, comparable to the extent of changes in the permafrost area in the next decades, although increases in temperatures, and the large scale patterns of future snow depth and precipitation are consistent across climate projections.

The estimates on peat volume are based on assumptions regarding the carbon content in peat and the bulk density of peat (see Sect. 2.3). Changing the peat bulk density from 100 to 80 increases the peat volume to $4200 \mathrm{~km}^{3}$ whereas a peat bulk density of $120 \mathrm{~kg} \mathrm{~m}^{-3}$ would yield a volume of peat of only $2800 \mathrm{~km}^{3}$.

\section{Conclusions}

Consistent with observations for the recent decades and with other model simulations of soil temperatures under future climate conditions, we find a widespread degradation of permafrost in Northern regions by the end of the century. Explicitly considering the distribution and depth of Northern peatlands showed that the insulating properties of peat lead to a considerably higher persistence of permafrost in peat soil compared to mineral soils and consequently delayed degradation of permafrost in peatland areas.

Our analyses bring up the important consideration of seasonality in predicting the impacts of climate change on $\mathrm{C} \mathrm{cy-}$ cling and storage within permafrost ecosystems. We found a 25 day earlier initiation of the spring frost-free season, and a 13 day extension of the fall frost-free period.

Despite the slower rate of soil warming in peatland areas and a slow degradation of permafrost under peat soils, a considerable volume of peat, approximately an additional $20 \%$ of the total volume of $3480 \mathrm{~km}^{3}$ of peat in Alaska and Canada, will be thawed by the end of the century. The potential release of carbon and the net effect of this thawing will depend on the balance between increased productivity and respiration, and will be mitigated by peat moisture.

Permafrost thaw often leads to collapse areas overlying ice-rich permafrost, and the formation of fens within existing permafrost peatlands (e.g. Beilman et al., 2001; Turetsky et al., 2007) or in areas that were formerly forested (Jorgenson et al., 2001). Jorgensen et al. (2001) estimate a $9 \%$ increase in peatland area in the Tanana Flats of interior Alaska from formerly forested areas. Often, these thaw collapse fens are more wetter, more productive and sequester more carbon following permafrost thaw (Camill et al., 2001).

Future improvements in predictive models that help understand the role of peatlands in the global climate system and their role as a source or sink of carbon under changing climate conditions will therefore depend on coupling the thermodynamical model with a hydrological model with an appropriate parameterization of peat hydraulic properties that is able to simulate the soil moisture and water table dynamics in peatlands. As this parameterization depends on the type peatland (e.g., fen vs. bog), improved modeling approaches will require a consistent methodology to map peatlands at the global scale.

Acknowledgements. Funding was provided by the National Science Foundation (NSF-ATM \#0628399, NSF RC-1021300, ARC-0632400, and ARC-0856864), NASA(\#NNX09AQ36G) and by the NASA-UNH Research \& Discover Program. We thank C. Tarnocai for providing the NCSCD data.

Edited by: P. Canadell

\section{References}

Åkerman, H. J. and Johansson, M.: Thawing permafrost and thicker active layers in sub-arctic Sweden, Permafrost Periglac. Process., 19(3), 279-292, 2008.

Alexeev, V. A., Nicolsky, D. J., Romanovsky, V. E., and Lawrence, D. M.: An evaluation of deep soil configurations in the CLM3 for improved representation of permafrost, Geophys. Res. Lett., 34(7), L09502, doi:10.1029/2007GL029536, 2007.

Anisimov, O. and Reneva, S.: Permafrost and Changing Climate: The Russian Perspective, Ambio, 35(4), 169-175, 2009.

Anisimov, O. A.: Potential feedback of thawing permafrost to the global climate system through methane emission, Environ. Res. Lett., 2(4), 045016, doi:10.1088/1748-9326/2/4/045016, 2007.

Anisimov, O. A., Shiklomanov, N. I., and Nelson, F. E.: Global warming and active-layer thickness: results from transient general circulation models, Global Planet. Change, 15(3-4), 61-77, 1997.

Anisimov, O. A., Lobanov, V. A., Reneva, S. A., Shiklomanov, N. I., Zhang, T., and Nelson, F. E.: Uncertainties in gridded air temperature fields and effects on predictive active layer modeling, J. Geophys. Res., 112(F2), F02S14, doi:10.1029/2006JF000593, 2007.

Arctic Climate Impact Assessment - ACIA: Impact of a Warming Arctic: Arctic Climate Impact Assessment, Cambridge University Press, 2004.

Aselmann, J. and Crutzen, P. J.: Global distribution of natural freshwater wetlands, rice paddies, their net primary production, seasonality, and possible methane emissions, J. Atmos. Chem., 8, 307-358, 1989.

Beilman, D. W., Vitt, D. H., and Halsey, L. A.: Localized permafrost peatlands in western Canada: definition, distributions, and degradation, Arct. Antarct. Alpine Res., 33, 70-77, 2001. 
Beringer, J., Lynch, A. H., Chapin, F. S., Mack, M., and Bonan, G. B.: The Representation of Arctic Soils in the Land Surface Model: The Importance of Mosses, J. Climate, 14(15), 33243335, 2001.

Bockheim, J. G., Walker, D. A., and Everett, L. R.: Soil carbon distribution in nonacidic and acidic tundra of Arctic Alaska, In: Soil Processes and the Carbon Cycle, edited by: Lal, R., Kimble, J. M., Follet, R. F., and Stewart, B. A., CRC Press, 143-155, 1997.

Boike, J., Hagedorn, B., and Roth, K.: Heat and Water Transfer Processes in Permafrost-Affected Soils: A Review of Field and Modeling-Based Studies for the Arctic and Antarctic, Ninth International Conference on Permafrost, 2009.

Bonan, G. B.: Ecological Climatology, Cambridge University Press, 2002.

Brown, J., Hinkel, K. M., and Nelson, F. E.: The circumpolar active layer monitoring (CALM) program: Research designs and initial results, Polar Geogr., 24(3), 166-258, 2000.

Brown, J., Ferrians Jr., O. J., Heginbottom, J. A., and Melnikov, E. S.: Circum-Arctic map of permafrost and ground-ice conditions, National Snow and Ice Data Center/World Data Center for Glaciology, Digital Media, Boulder, CO, 2001.

Camill, P.: Permafrost Thaw Accelerates in Boreal Peatlands During Late-20th Century Climate Warming, Climatic Change, 68(1), 135-152, 2005.

Camill, P., Lynch, J. A., Clark, J. S., Adams, J. B., and Jordan, B.: Changes in biomass, aboveground net primary production, and peat accumulation following permafrost thaw in the boreal peatlands of Manitoba, Canada, Ecosystems, 4(5), 461-478, 2001.

Carrasco, J. J., Neff, J. C., and Harden, J. W.: Modeling physical and biogeochemical controls over carbon accumulation in a boreal forest soil, J. Geophys. Res., 111, G02004, doi:10.1029/2005JG000087, 2006.

Chason, D. B. and Siegel, D. I.: Hydraulic Conductivity and Related Physical Properties of Peat, Lost River Peatland, Northern Minnesota, Soil Sci., 142(2), 91-99, 1986.

Christensen, T. R., Johansson, T., Åkerman, H. J., Mastepanov, M., Malmer, N., Friborg, T., Crill, P., and Svensson, B. H.: Thawing sub-arctic permafrost: Effects on vegetation and methane emissions, Geophys. Res. Lett., 31, L04501, doi:10.1029/2003GL018680, 2004.

Dorrepaal, E., Toet, S., van Logtestijn, R. S. P., Swart, E., van de Weg, M. J., Callaghan, T. V., and Aerts, R.: Carbon respiration from subsurface peat accelerated by climate warming in the subarctic, Nature, 460(7255), 616-619, 2009.

Dye, D. G.: Variability and trends in the annual snow-cover cycle in Northern Hemisphere land areas, 1972-2000, Hydrol. Processe., 16(15), 3065-3077, 2002.

Dyer, J. L. and Mote, T. L.: Spatial variability and trends in observed snow depth over North America, Geophys. Res. Lett., 33(16), L16503, doi:10.1029/2006GL027258, 2006.

Elberling, B., Christiansen, H. H., and Hansen, B. U.: High nitrous oxide production from thawing permafrost, Nat. Geosci., 3(5), 332-335, 2010.

Ershov, E. D.: Methods of geocryological investigation, Moscow State University Press, p.512, 2004.

Euskirchen, E. S., McGuire, A. D., Kicklighter, D. W., Zhuang, Q., Clein, J. S., Dargaville, R. J., Dye, D. G., Kimball, J. S., McDonald, K. C., Melillo, J. M., Romanovsky, V.
E., and Smith, N. V.: Importance Of Recent Shifts In Soil Thermal Dynamics On Growing Season Length, Productivity, And Carbon Sequestration In Terrestrial High-Latitude Ecosystems, Global Change Biol., 12, 731-750, doi:10.1111/j.13652486.2006.01113.x, 2006.

Farouki, O. T.: The thermal properties of soils in cold regions, Cold Reg. Sci. Technol., 5(1), 67-75, 1981.

Frey, K. E. and Smith, L. C.: Amplified carbon release from vast West Siberian peatlands by 2100, Geophys. Res. Lett., 32(7), L09401, doi:10.1029/2004GL022025, 2005.

Friedl, M. A., McIver, D. K., Hodges, J. C. F., Zhang, X. Y., Muchoney, D., Strahler, A. H., Woodcock, C. E., Gopal, S., Schneider, A., Cooper, A., Baccini, A., Gao, F., and Schaaf, C.: Global land cover mapping from MODIS: algorithms and early results, Remote Sens. Environ., 83(1-2), 287-302, doi:10.1016/S00344257(02)00078-0, 2002.

Frolking, S., Roulet, N., and Lawrence, D.: Issues Related to Incorporating Northern Peatlands Into Global Climate Models, in: Carbon Cycling in Northern Peatlands, edited by: Baird, A. J., Belyea, L. R., Comas, X., Reeve, A. S., and Slater, L. D., American Geophysical Union, 184, 299, 2009.

Fukui, K., Sone, T., Yamagata, K., Otsuki, Y., Sawada, Y., Vetrova, V., and Vyatkina, M.: Relationships between permafrost distribution and surface organic layers near Esso, central Kamchatka, Russian Far East, Permafrost Periglac. Process., 19(1), 85-92, doi:10.1002/ppp.606, 2008.

Gedney, N., Cox, P. M., and Huntingford, C.: Climate feedback from wetland methane emissions, Geophys. Res. Lett., 31(20), L20503, doi:10.1029/2004GL020919, 2004.

Global Soil Data Task Group: Global Gridded Surfaces of Selected Soil Characteristics (IGBP-DIS), Data set, available online http://www.daac.ornl.gov (last access: 15 June 2011), from Oak Ridge National Laboratory Distributed Active Archive Center, Oak Ridge, Tennessee, USA, doi:10.3334/ORNLDAAC/569, 2002.

Gorham, E.: Northern Peatlands - Role in the Carbon-Cycle and Probable Responses to Climatic Warming, Ecol. Appl., 1(2), 182-195, 1991.

Gray, D. M. and Prowse, T. D.: Snow and Floating Ice, Handbook of Hydrology, D. R. Maidment, McGraw-Hill, 1993.

Halsey, L. A., Vitt, D. H., and Zoltai, S. C.: Disequilibrium response of permafrost in boreal continental western Canada to climate change, Climatic Change, 30(1), 57-73, doi:10.1007/BF01093225, 1995.

Hamon, W. R.: Computation of direct runoff amounts from storm rainfall, Int. Assoc. Sci. Hydrol. Pub., 63, 52-62, 1963.

Heginbottom, J. A.: Permafrost mapping: a review, Progr. Phys. Geogr., 26(4), 623-642, 2002.

Hendrickx, J. M. H., Xie, H., Harrison, J. B. J., Borchers, B., and Simunek, J.: Global prediction of thermal soil regimes, SPIE, 2008.

Hinkel, K. M. and Nelson, F. E.: Spatial and temporal patterns of active layer thickness at Circumpolar Active Layer Monitoring (CALM) sites in northern Alaska, 1995\&\#8211;2000, J. Geophys. Res., 108(D2), 8168, 2003.

Hossain, M. F., Zhang, Y., Chen, W., Wang, J., and Pavlic, G.: Soil organic carbon content in northern Canada: A database of field measurements and its analysis, Can. J. Soil Sci., 87, 259-268, 2007. 
Ise, T., Dunn, A. L., Wofsy, S. C., and Moorcroft, P. R.: High sensitivity of peat decomposition to climate change through watertable feedback, Nat. Geosci., 1(11), 763-766, 2008.

Jorgenson, M. T., C. H. Racine, J. C. Walters and T. E. Osterkamp: Permafrost degradation and ecological changes associated with a warming climate in central Alaska, Climatic Change, 48(4), 551-579, 2001.

Jorgenson, M. T., Romanovsky, V., Harden, J., Shur, Y., O’Donnell, J., Schuur, E. A. G., Kanevskiy, M., and Marchenko, S.: Resilience and vulnerability of permafrost to climate change, Can. J. Forest Res., 40(5), 1219-1236, 2010.

Kettridge, N. and Baird, A.: Modelling soil temperatures in northern peatlands, Eur. J. Soil Sci., 59(2), 327-338, 2008.

Kingsbury, C. M. and Moore, T. R.: The Freeze-Thaw Cycle of a Subarctic Fen, Northern Quebec, Canada, Arctic Alpine Res., 19(3), 289-295, 1987.

Kujala, K., Seppälä, M., and Holappa, T.: Physical properties of peat and palsa formation, Cold Reg. Sci. Technol., 52(3), 408414, 2008

Lafleur, P. M. and Humphreys, E. R.: Spring warming and carbon dioxide exchange over low Arctic tundra in central Canada, Global Change Biol., 14(4), 740-756, 2008.

Lawrence, D. and Slater, A.: The contribution of snow condition trends to future ground climate, Clim. Dynam., 34(5), 969-981, 2010.

Lawrence, D. M. and Slater, A. G.: A projection of severe nearsurface permafrost degradation during the 21 st century, Geophys. Res. Lett., 32(24), L24401, doi:10.1029/2005GL025080, 2005.

Lawrence, D. M. and Slater, A. G.: Incorporating organic soil into a glocal climate model, Clim. Dynam., 30, 145-160, 2008.

Lawrence, D. M., Slater, A. G., Romanovsky, V. E., and Nicolsky, D. J.: Sensitivity of a model projection of near-surface permafrost degradation to soil column depth and representation of soil organic matter, J. Geophys. Res.-Earth, 113(F2), F02011, doi:10.1029/2007JF000883, 2008.

Limpens, J., Berendse, F., Blodau, C., Canadell, J. G., Freeman, C., Holden, J., Roulet, N., Rydin, H., and Schaepman-Strub, G.: Peatlands and the carbon cycle: from local processes to global implications - a synthesis, Biogeosciences, 5, 1475-1491, doi:10.5194/bg-5-1475-2008, 2008.

Lund, M. P., Lafleur, P. M., Roulet, N. T., Lindroth, A., Christensen, T. R., Aurela, M., Chojnicki, B. H., Flanagan, L. B., Humphreys, E. R., Laurila, T., Oechel, W. C., Olejnik, J., Rinne, J., Schubert, P., and Nilsson, M. B.: Variability in exchange of $\mathrm{CO}_{2}$ across 12 northern peatland and tundra sites. Global Change Biol., 16(7), 2436-2448, 2010.

Marchenko, S., Romanovsky, V., and Tipenko, G.: Numerical Modeling of Spatial Permafrost Dynamics in Alaska, Ninth International Conference on Permafrost, Fairbanks, Alaska, 2008.

Marchenko, S. S.: A model of permafrost formation and occurrences in the intracontinental mountains, Norsk Geografisk Tidsskrift, Norw. J. Geogr., 55(4), 230-234, 2001.

Matthews, E. and Fung, I.: Methane Emission From Natural Wetlands: Global Distribution, Area, and Environmental Characteristics of Sources, Global Biogeochem. Cy., 1(1), 61-86, 1987.

Meehl, G. A., Stokcer, T. F., Collins, W. D., Fiedlingstein, P., Gaye, A. T., Gregory, J. M., Kitoh, A., Knutti, R., Murphy, J. M., Noda, A., Raper, S. C. B., Watterson, I. G., Weaver, A. J., and Zhao, Z. C.: Global Climate Projections, Climate Change 2007:
The Physical Science Basis, Contribution of Working Group I to the Fourth Assessment Report of the Intergovernmental Panel on Climate Change, edited by: Solomon, S., Qin, D., Manning, M., Chen, Z., Marquis, M. B., Averyt, K.. Tignor, M., and Hiller, H. L., Cambridge University Press, 2007.

NCAR - National Center for Atmospheric Research:The NCAR Command Language Reference Manual, available online at http: //ncl.ucar.edu (last assess: 10 March 2011), 2011.

Nelson, F. E., Shiklomanov, N. I., Mueller, G. R., Hinkel, K. M., Walker, D. A., and Bockheim, J. G.: Estimating Active-Layer Thickness over a Large Region: Kuparuk River Basin, Alaska, USA, Arctic Alpine Res., 29(4), 367-378, 1997.

Nicolsky, D. J., Romanovsky, V. E., and Panteleev, G. G.: Estimation of soil thermal properties using in-situ temperature measurements in the active layer and permafrost, Cold Reg. Sci. Technol., 55(1), 120-129, 2009.

O’Donnell, J. A., Romanovsky, V. E., Harden, J. W., and McGuire, A. D.: "The Effect of Moisture Content on the Thermal Conductivity of Moss and Organic Soil Horizons From Black Spruce Ecosystems in Interior Alaska, Soil Sci., 174(12), 646-651, doi:10.1097/SS.0b013e3181c4a7f8, 2009.

Oberman, N. G. and Mazhitova, G. G.: Permafrost dynamics in the north-east of European Russia at the end of the 20th century, Norsk Geografisk Tidsskrift, Norw. J. Geogr., 55(4), 241-244, 2001.

Osterkamp, T. E.: The recent warming of permafrost in Alaska, Global Planet. Change, 49(3-4), 87-202, doi:10.1016/j.gloplacha.2005.09.001, 2005.

Payette, S., Delwaide, A., Caccianiga, M., and Beauchemin, M.: Accelerated thawing of subarctic peatland permafrost over the last 50 years, Geophys. Res. Lett., 31, L18208, doi:10.1029/2004GL020358, 2004.

Piao, S. L., Friedlingstein, P., Ciais, P., de Noblet-Ducoudre, N., Labat, D., and Zaehle , S.: Changes in climate and land use have a larger direct impact than rising $\mathrm{CO}_{2}$ on global river runoff trends, P. Natl. Acad. Sci. USA, 104(39), 15242-15247, 2007.

Rawlins, M. A., Lammers, R. B., Frolking, S., Fekete, B. M., and Vörösmarty, C. J.: Simulating pan-Arctic runoff with a macroscale terrestrial water balance model, Hydrol. Process., 17(13), 2521-2539, 2003.

Rawlins, M. A., Steele, M., Holland, M. M., Adam, J. C., Cherry, J. E., Francis, J. A., Groisman, P. Y., Hinzman, L. D., Huntington, T. G., Kane, D. L., Kimball, J. S., Kwok, R., Lammers, R. B., Lee, C. M., Lettenmaier, D. P., McDonald, K. C., Podest, E., Pundsack, J. W., Rudels, B., Serreze, M. C., Shiklomanov, A., Skagseth, Ö, Troy, T. J., Vörösmarty, C. J., Wensnahan, M., Wood, E. F., Woodgate, R., Yang, D., Zhang, K., and Zhang, T.: Analysis of the Arctic System for Freshwater Cycle Intensification: Observations and Expectations, J. Climate, 23(21), 57155737, 2010.

Richardson, A. D., Andy Black, T., Ciais, P., Delbart, N., Friedl, M. A., Gobron, N., Hollinger, D. Y., Kutsch, W. L., Longdoz, B., Luyssaert, S., Migliavacca, M., Montagnani, L., William Munger, J., Moors, E., Piao, S., Rebmann, C., Reichstein, M., Saigusa, N., Tomelleri, E., Vargas, R., and Varlagin, A.: Influence of spring and autumn phenological transitions on forest ecosystem productivity, Philos. T. Roy. Soc. B, 365(1555), 32273246, 2010. 
Rinke, A., Kuhry, P., and Dethloff, K.: Importance of a soil organic layer for Arctic climate: A sensitivity study with an Arctic RCM, Geophys. Res. Lett., 35(13), L13709, doi:10.1029/2008GL034052, 2008.

Roeckner, E., Bäumla, G., Bonaventura, L., Brokopf, R., Esch, M., Giorgetta, M., Hagemann, S., Kirchner, I., Kornblueh, L., Manzini, E., Rhodin, A., Schlese, U., Schulzweida, U., and Tompkins, A.: The Atmosphere General Circulation Model ECHAM5, Max-Planck-Institut für Meteorologie, Hamburg, Germany, 2003.

Romanovsky, V. E. and Osterkamp, T. E.: Thawing of the Active Layer on the Coastal Plain of the Alaskan Arctic, Permafrost Periglac. Process., 8(1), 1-22, 1997.

Romanovsky, V. E. and Osterkamp, T. E.: Effects of unfrozen water on heat and mass transport processes in the active layer and permafrost.” Permafrost Periglac. Process., 11(3), 219-239, 2000.

Romanovsky, V. E., Gruber, S., Instanes, A., Jin, H., Marchenko, S. S., Smith, S. L., Trombotto, D., and Walter, K. M.: Frozen Ground, Global Outlook for Ice and Snow, Arendal, Norway, Earthprint, United Nations Environment Programme/GRID, 181-200, 2007.

Romanovsky, V. E., Smith, S. L., and Christiansen, H. H.: Permafrost thermal state in the polar Northern Hemisphere during the international polar year 2007-2009: a synthesis, Permafrost Periglac. Process., 21(2), 106-116, 2010.

Rydin, H. and Jeglum, J.: The biology of peatlands, Oxford, Oxford University Press, 2006.

Schimel, J. P., Bilbrough, C., and Welker, J. M.: Increased snow depth affects microbial activity and nitrogen mineralization in two Arctic tundra communities, Soil Biol. Biochem., 36(2), 217227, 2004

Schimel, J. P., Fahnestock, J., Michaelson, G., Mikan, C., Ping, C.-L., Romanovsky, V. E., and Welker, J.: Cold-season Production of $\mathrm{CO}_{2}$ in Arctic Soils: Can Laboratory and Field Estimates Be Reconciled through a Simple Modeling Approach?, Arct. Antarct. Alp. Res., 38(2), 249-256, 2006.

Schuur, E. A. G., Bockheim, J., Canadell, J. G., Euskirchen, E., Field, C. B., Goryachkin, S. V., Hagemann, S., Kuhry, P., Lafleur, P. M., Lee, H., Mazhitova, G., Nelson, F. E., Rinke, A., Romanovsky, V. E., Shiklomanov, N., Tarnocai, C., Venevsky, S., Vogel, J. G., and Zimov, S. A.: Vulnerability of Permafrost Carbon to Climate Change: Implications for the Global Carbon Cycle, Bioscience, 58(6), 701-714, 2008.

Schuur, E. A. G., Vogel, J. G., Crummer, K. G., Lee, H., Sickman, J. O., and Osterkamp, T. E.: The effect of permafrost thaw on old carbon release and net carbon exchange from tundra, Nature, 459(7246), 556-559, 2009.

Shiklomanov, N. I., Anisimov, O. A., Zhang, T., Marchenko, S., Nelson, F. E., and Oelke, C.: Comparison of model-produced active layer fields: Results for northern Alaska, J. Geophys. Res., 112(F2), F02S10, doi:10.1029/2006JF000571, 2007.

Shur, Y. L. and Jorgenson, M. T.: Patterns of permafrost formation and degradation in relation to climate and ecosystems, Permafrost Periglac. Process., 18, 7-19, doi:10.1002/ppp.582, 2007.

Simon, T. and Serge, P.: Recent permafrost degradation in bogs of the James Bay area, northern Quebec, Canada, Permafrost Periglac. Process., 20(4), 383-389, 2009.
Smith, L. C., Sheng, Y., and Macdonald, G. M.: A first pan-Arctic assessment of the influence of glaciation, permafrost, topography and peatlands on northern hemisphere lake distribution, Permafrost Periglac. Process., 18, 201-208, 2007.

Smith, M. W. and Riseborough, D. W.: Climate and the limits of permafrost: a zonal analysis, Permafrost Periglac. Process., 13(1), 1-15, 2002.

Smith, N. V., Saatchi, S. S., and Randerson, J. T.: Trends in high northern latitude soil freeze and thaw cycles from 1988 to 2002, J. Geophys. Res., 109, D12101, doi:10.1029/2003JD004472, 2004.

Smith, S. L., Wolfe, S. A., Riseborough, D. W., and Nixon, F. M.: Active-layer characteristics and summer climatic indices, Mackenzie Valley, Northwest Territories, Canada, Permafrost Periglac. Process., 20(2), 201-220, 2009.

Smith, S. L., Romanovsky, V. E., Lewkowicz, A. G., Burn, C. R., Allard, M., Clow, G. D., Yoshikawa, K., and Throop, J.: Thermal state of permafrost in North America: a contribution to the international polar year, Permafrost Periglac. Process., 21(2), 117135, 2010.

St-Hilaire, F., Wu, J., Roulet, N. T., Frolking, S., Lafleur, P. M., Humphreys, E. R., and Arora, V.: McGill wetland model: evaluation of a peatland carbon simulator developed for global assessments, Biogeosciences, 7, 3517-3530, doi:10.5194/bg-7-35172010, 2010.

Stendel, M. and Christensen, J. H.: Impact of global warming on permafrost conditions in a coupled GCM, Geophys. Res. Lett., 29(13), 1632, 2002.

Stieglitz, M., Déry, S. J., Romanovsky, V. E., and Osterkamp, T. E.: The role of snow cover in the warming of arctic permafrost, Geophys. Res. Lett., 30(13), 1721, 2003.

Strack, M., Waddington, J. M., Turetsky, M., Roulet, N. T., and Byrne, K. A.: Northern peatlands, greenhouse gas exchange, and climate change, in: Peatlands and climate change, edited by: Strack, M., International Peat Society, 2008.

Sturm, M., Holmgren, J., König, M., and Morris, K.: The thermal conductivity of seasonal snow, J. Glaciol., 43(143), 26-41, 1997.

Sturm, M., Douglas, T., Racine, C., and Liston, G. E.: Changing snow and shrub conditions affect albedo with global implications, J. Geophys. Res., 110, G01004, doi:10.1029/2005JG000013, 2005.

Tarnocai, C.: The effect of climate change on carbon in Canadian peatlands, Global Planet. Change, 53(4), 222-232, 2006.

Tarnocai, C., Canadell, J. G., Schuur, E. A. G., Kuhry, P., Mazhitova, G., and Zimov, S.: Soil organic carbon pools in the northern circumpolar permafrost region, Global Biogeochem. Cy., 23(2), GB2023, doi:10.1029/2008GB003327, 2009.

Tice, A. R., Anderson, D. M., and Banin, A.: The prediction of unfrozen water contents in frozen soils from liquid limit determinations, CRREL Report, 1976.

Treat, C. C., Bubier, J. L., Varner, R. K., and Crill, P. M.: Timescale dependence of environmental and plant-mediated controls on $\mathrm{CH}_{4}$ flux in a temperate fen, J. Geophys. Res., 112, G01014, doi:10.1029/2006JG000210, 2007.

Treat, C. C.: Modeling permafrost stability in peatlands with climate change and disturbance, M. Sc. Thesis, Department of Earth Sciences, University of New Hampshire, Durham, NH, 104 pp., 2010. 
Treat, C. C., Wisser, D., Frolking, S., Marchenko, S., and Huemmrich, K. F.: Relative impacts of cli- mate change and disturbance on permafrost stability in northern organic soils, in preparation for Permafrost Periglac. Proc., 2011.

Turetsky, M. R., Wieder, R. K., and Vitt, D. H.: Boreal peatland $\mathrm{C}$ fluxes under varying permafrost regimes, Soil Biol. Biochem., 34(7), 907-912, 2002.

Turetsky, M. R., Wieder, R. K., Vitt, D. H., Evans, R. J., and Scott, K. D.: The disappearance of relict permafrost in boreal north America: Effects on peatland carbon storage and fluxes, Global Change Biol., 13(7), 1922-1934, 2007.

Turetsky, M. R., Treat, C. C., Waldrop, M. P., Waddington, J. M., Harden, J. W., and McGuire, A. D.: Short-term response of methane fluxes and methanogen activity to water table and soil warming manipulations in an Alaskan peatland, J. Geophys. Res.-Biogeo., 113, G00A10, doi:10.1029/2007JG000496, 2008.

Turunen, J. and Moore, T. R.: Controls on carbon accumulation and storage in the mineral subsoil beneath peat in Lakkasuo mire, central Finland, Eur. J. Soil Sci., 54, 279-286, 2003.

Turunen, J., Tahvanainen, T., Tolonen, K., and Pitkanen, A.: Carbon accumulation in West Siberian mires, Russia, Global Biogechem. Cy., 15(285), 285-296, 2001.

Turunen, J., Tomppo, E., Tolonen, K., and Reinikainen, A.: Estimating carbon accumulation rates of undrained mires in Finlandapplication to boreal and subarctic regions, Holocene, 12(1), 6980, 2002.

van Everdingen, R. O.: Multi-language glossary of permafrost and related ground ice terms, Boulder, CO, International Permafrost Association, 1989.

Vitt, D., Halsey, L. A., and Zoltai, S. C.: The bog landforms of continental western Canada in relation to climate and permafrost patterns, Arctic Alpine Res., 26(1), 1-13, 1994.

Vitt, D., Wieder, R., Scott, K., and Faller, S.: Decomposition and Peat Accumulation in Rich Fens of Boreal Alberta, Canada, Ecosystems, 12(3), 360-373, 2009.

Walsh, J. E., Chapman, W. L., Romanovsky, V., Christensen, J. H., and Stendel, M.: Global climate model performance over Alaska and Greenland, J. Climate, 21, 6156-6174, 2008.

Wania, R., Ross, I., and Prentice, I. C.: Integrating peatlands and permafrost into a dynamic global vegetation model: 1 . Evaluation and sensitivity of physical land surface processes, Global Biogeochem. Cy., 23(3), GB3014, doi:10.1029/2008GB003413, 2009.

Webb, R. W., Rosenzweig, C. E., and Levine, E. R.: Global Soil Texture and Derived Water-Holding Capacities, Oak Ridge National Laboratory Distributed Active Archive Center, 2000.

Weiss, R., Shurpali, N. J., Sallantaus, T., Laiho, R., Laine, J., and Alm, J.: Simulation of water table level and peat temperatures in boreal peatlands, Ecol. Modell., 192(3-4), 441-456, 2006.

Willmott, C. J., Rowe, C. N., and Mintze, Y.: Climatology of the terrestrial seasonal water cycle, J. Climatol., 43, 495-511, 1995.
Wisser, D., Fekete, B. M., Vörösmarty, C. J., and Schumann, A. H.: Reconstructing 20th century global hydrography: a contribution to the Global Terrestrial Network- Hydrology (GTN-H), Hydrol. Earth Syst. Sci., 14, 1-24, doi:10.5194/hess-14-1-2010, 2010.

Wright, N., Hayashi, M., and Quinton, W. L.: Spatial and temporal variations in active layer thawing and their implication on runoff generation in peat-covered permafrost terrain, Water Resour. Res., 45(5), W05414, doi:10.1029/2008WR006880, 2009.

Yang, K. and Koike, T.: Comments on "Estimating Soil Water Contents from Soil Temperature Measurements by Using an Adaptive Kalman Filter", J. Appl. Meteorol., 44(4), 546-550, 2005.

Yano, Y., Shaver, G. R., Giblin, A. E., Rastetter, E. B., and Nadelhoffer, K. J.: Nitrogen dynamics in a small arctic watershed: retention and downhill movement of 15 N, Ecol. Monogr., 80(2), 331-351, 2010.

Yi, S., Arain, M. A., and Woo, M.-K.: Modifications of a land surface scheme for improved simulation of ground freeze-thaw in northern environments, Geophys. Res. Lett., 33, L13501, doi:10.1029/2006GL026340, 2006.

Yi, S., Woo, M., and Arain, M. A.: Impacts of peat and vegetation on permafrost degradation under climate warming, Geophys. Res. Lett., 34, L16504, doi:10.1029/2007GL030550, 2007.

Yi, S., Manies, K., Harden, J., and McGuire, A. D.: Characteristics of organic soil in black spruce forests: Implications for the application of land surface and ecosystem models in cold regions, Geophys. Res. Lett., 36(5), L05501, doi:10.1029/2008GL037014, 2009.

Yu, Z., Loisel, J., Brosseau, D. P., Beilman, D. W., and Hunt, S. J.: Global peatland dynamics since the Last Glacial Maximum, Geophys. Res. Lett., 37(13), L13402, doi:10.1029/2010GL043584, 2010.

Zhang, T., Barry, R. G., Knowles, K., Heginbottom, J. A., and Brown, J.: Statistics and characteristics of permafrost and ground ice distribution in the Northern Hemisphere, Polar Geogr., 23(2), 147-169, 1999.

Zhang, Y., Chen, W., and Riseborough, D. W.: Modeling longterm dynamics of snow and their Impacts on permafrost in Canada, Proceedings of the Ninth International Conference on Permafrost, 2055-2060, 2008a.

Zhang, Y., Chen, W., and Riseborough, D. W.: Transient projections of permafrost distribution in Canada during the 21 st century under scenarios of climate change, Global Planet. Change, 60(3-4), 443-456, 2008b.

Zhang, Y., Carey, S. K., Quinton, W. L., Janowicz, J. R., Pomeroy, J. W., and Flerchinger, G. N.: Comparison of algorithms and parameterisations for infiltration into organic-covered permafrost soils, Hydrol. Earth Syst. Sci., 14, 729-750, doi:10.5194/hess14-729-2010, 2010.

Zimov, S. A., Schuur, E. A. G., and Chapin, F. S.: Permafrost and the global carbon budget, Science, 312(5780), 1612-1613, 2006

Zoltai, S. C., Morissey, L. A., Livingston, G. P., and Groot, W. J. D.: Effects of fires on carbon cycling in North American boreal peatlands, Environ. Rev.,6, 13-24, 1998. 